\title{
Impact of Different Daily Light Integrals and Carbon Dioxide Concentrations on the Growth, Morphology, and Production Efficiency of Tomato Seedlings
}

\author{
Brandon M. Huber, Frank J. Louws and Ricardo Hernández* \\ Department of Horticultural Sciences, North Carolina State University, Raleigh, NC, United States
}

\section{OPEN ACCESS}

Edited by:

Bernard Grodzinski,

University of Guelph, Canada

Reviewed by:

Theoharis Ouzounis,

Fluence Bioengineering, Inc.,

United States

Jason Lanoue,

Agriculture and Agri-Food Canada

(AAFC), Canada

*Correspondence:

Ricardo Hernández

ricardo_hernandez@ncsu.edu

Specialty section:

This article was submitted to Crop and Product Physiology,

a section of the journal

Frontiers in Plant Science

Received: 10 October 2020

Accepted: 08 February 2021

Published: 03 March 2021

Citation:

Huber BM, Louws FJ and

Hernández R (2021) Impact of Different Daily Light Integrals and Carbon Dioxide Concentrations

on the Growth, Morphology, and Production Efficiency of Tomato

Seedlings.

Front. Plant Sci. 12:615853. doi: 10.3389/fpls.2021.615853
Indoor growing systems with light-emitting diodes offer advantages for the growth of tomato seedlings through uniform and optimized environmental conditions which increase consistency between plants and growing cycles. $\mathrm{CO}_{2}$ enrichment has been shown to improve the yield of crops. Thus, this research aimed to characterize the effects of varied light intensities and $\mathrm{CO}_{2}$ enrichment on the growth, morphology, and production efficiency of tomato seedlings in indoor growing systems. Four tomato cultivars, "Florida-47 R," "Rebelski," "Maxifort," and "Shin Cheong Gang," were subjected to three different daily light integrals (DLIs) of 6.5, 9.7, and $13 \mathrm{~mol} \mathrm{~m}^{-2}$ $\mathrm{d}^{-1}$ with a percent photon flux ratio of 40 blue:60 red and an end-of-day far-red treatment of $5 \mathrm{mmol} \mathrm{m} \mathrm{m}^{-2} \mathrm{~d}^{-1}$. The plants were also subjected to three different $\mathrm{CO}_{2}$ concentrations: $448 \pm 32$ (400-ambient), $1010 \pm 45$ (1000), and $1568 \pm 129$ (1600) $\mu \mathrm{mol} \mathrm{mol}^{-1}$. Temperature was maintained at $24.3^{\circ} \mathrm{C} \pm 0.48 / 16.8^{\circ} \mathrm{C} \pm 1.1$ (day/dark; $22.4^{\circ} \mathrm{C}$ average) and relative humidity at $52.56 \pm 8.2 \%$. Plant density was 1000 plants $\mathrm{m}^{-2}$ until canopy closure. Morphological measurements were conducted daily to observe the growth response over time. In addition, data was collected to quantify the effects of each treatment. The results showed increases in growth rate with increases in the $\mathrm{DLI}$ and $\mathrm{CO}_{2}$ concentration. In addition, $\mathrm{CO}_{2}$ enrichment to 1000 $1600 \mu \mathrm{mol} \mathrm{mol}{ }^{-1}$ increased the light use efficiency (9DM mol-1 applied) by 38-44\%, and $\mathrm{CO}_{2}$ enrichment to $1600 \mu \mathrm{mol} \mathrm{mol}{ }^{-1}$ did not result in any additional increase on shoot fresh mass, shoot dry mass, and stem extension. However, the net photosynthetic rate obtained with $1600 \mu \mathrm{mol} \mathrm{mol}{ }^{-1}$ was 31 and $68 \%$ higher than those obtained with 1000 and $400 \mathrm{\mu mol} \mathrm{mol}^{-1}$, respectively. Furthermore, the comparison of the light and $\mathrm{CO}_{2}$ treatment combinations with the control $\left(13 \mathrm{~mol} \mathrm{~m}-2 \mathrm{~d}^{-1}-400 \mathrm{CO}_{2}\right)$ revealed that the plants subjected to $6.5 \mathrm{DLI}-1600 \mathrm{CO}_{2}, 9.7 \mathrm{DLI}-1000 \mathrm{CO}_{2}$, and $9.7 \mathrm{DLI}-1600 \mathrm{CO}_{2}$ treatment combinations exhibited the same growth rate as the control plants but with $25-50 \%$ less DLI. Furthermore, two treatment combinations (13.0DLI-1000CO 2 and $13.0 \mathrm{DLI}-1600 \mathrm{CO}_{2}$ ) were associated with the consumption of comparable amount of energy but increased plant growth by $24-33 \%$.

Keywords: carbon dioxide, PPFD, controlled environment agriculture, vertical farm, light-emitting diodes, energy consumption, production cost 


\section{INTRODUCTION}

High-quality transplants include seedlings that are free of disease/pests, that are compact but have high fresh and dry masses, and that exhibit high uniformity in both morphology and development (Kozai, 2005; Kubota et al., 2008). Currently, tomato seedlings are commonly grown in greenhouses or high tunnels, but these systems are subject to fluctuations in external weather, seasonality and solar radiation and thus could lead to seedlings that exhibit low uniformity. Indoor controlled environment (indoor CE) systems that use light-emitting diodes (LEDs) as the sole source of light have several advantages over other controlled environments. For example, indoor CE systems exhibit higher control of all environmental conditions, including temperature, radiation, spectrum, $\mathrm{CO}_{2}$ concentration, air velocity, photoperiod, and vapor pressure deficit. In addition, spectral customization can enhance the biomass and growth of tomato seedlings (Hernández et al., 2016). When combined, these environmental components that are controlled in indoor $\mathrm{CE}$ systems can increase the resource and energy use efficiency of plants. In addition, indoor CE systems provide consistent plant quality independent of the weather and increase the spatial and temporal uniformity of the plants (Ohyama et al., 2000; Kozai, 2005; Kubota et al., 2008). Although these systems have a higher electrical energy use, the high planting density, and short production cycle make them economically feasible (Ohyama et al., 2003; Kozai, 2007, 2013; Kubota et al., 2008).

Tomato (Solanum lycopersicum Mill.) is widely grown around the world and is the second most valuable vegetable crop in the United States (U.S. Department of Agriculture, 2016). It is also one of the most consumed vegetables in the world and provides healthy nutrients and antioxidants (Shi and Le Maguer, 2000). In addition, the vast majority of the tomato seedlings grown are started in specialized nurseries and transplanted to greenhouses and the field (Lewis et al., 2014). Furthermore, the use of grafted tomato plants has become an essential cultivation strategy in many parts of the world (Singh et al., 2017). For example, grafted tomato plants represent a significant percentage of the total tomato plants grown in Netherlands (75\%), France (50\%), Japan (40\%), Korea (25\%), and Vietnam (33\%; Singh et al., 2017), and millions of grafted transplants are used in the United States, Italy, and Spain (Singh et al., 2017). Grafted tomato plants are utilized to increase plant vigor and thus achieve longer production cycles (Oda, 1999; Khah et al., 2006; Yarsi, 2011) and to confer disease resistance in tomato crops grown (Kaskavalci et al., 2009; Louws et al., 2010; Rivard et al., 2010; McAvoy et al., 2012). However, the propagation of grafted tomato plants at a large scale is a challenging process because the environmental conditions have to be adjusted to produce two plants (rootstock and scion) at the same growth rate to ensure proper stem matching (Kubota et al., 2008; Hu et al., 2016). Therefore, tomato transplants, including grafted seedlings, are suitable for indoor CE systems (Ohyama et al., 2003; Kozai, 2005; Nanfelt, 2016).

The light environment needs to be optimized to ensure desirable growth and reduce electricity consumption in indoor $\mathrm{CE}$ systems. The effects of the light intensity or photosynthetic photon flux density (PPFD) on the growth of tomato seedlings
(Fan et al., 2013; O'Carrigan et al., 2014) and mature fruiting plants (Dorais, 2003; Torres and Lopez, 2011; Hao et al., 2017) have been studied. In general, an increase in the PPFD or daily light integral (DLI) increases the biomass and flower developmental rate (Uzun, 2006; Fan et al., 2013; Gómez and Mitchell, 2015). For example, in a growth chamber study, Fan et al. (2013) found that the shoot dry mass of tomato seedlings increased by $230 \%$ when the DLI was increased from 2.2 to $23.0 \mathrm{~mol} \mathrm{~m}-2 \mathrm{~d}^{-1}$ and by $51 \%$ when the DLI was increased from 6.5 to $13.0 \mathrm{~mol} \mathrm{~m}^{-2} \mathrm{~d}^{-1}$. Similarly, the use of supplemental lighting in a greenhouse to increase the DLI by $5.1 \mathrm{~mol} \mathrm{~m}^{-2}$ $\mathrm{d}^{-1}$ increased the shoot dry mass of tomato seedlings by 200\% (Gómez and Mitchell, 2015). Although increasing the DLI generally increases growth, it is important to provide an adequate DLI to increase the production efficacy (growth per kilowatt hour). Fan et al. (2013) found that the best light level for tomato transplants was $13.0 \mathrm{~mol} \mathrm{~m}^{-2} \mathrm{~d}^{-1}$ because increasing the DLI beyond $23.0 \mathrm{~mol} \mathrm{~m}^{-2} \mathrm{~d}^{-1}$ resulted in only slight increases in the dry mass and no increase in the photosynthetic rate (Fan et al., 2013). Similarly, in tomato seedlings, O'Carrigan et al. (2014) showed that increasing the DLI from 17 to $27 \mathrm{~mol} \mathrm{~m}^{-2} \mathrm{~d}^{-1}$ only increased the shoot dry mass by $7 \%$.

$\mathrm{CO}_{2}$ is often supplemented in indoor CE systems (Kozai, 2018) and $\mathrm{CO}_{2}$ enrichment is inexpensive under low room air exchange $\left(0.001-0.1 \mathrm{~h}^{-1}\right)$, which is common for indoor CE systems (Ohyama and Kozai, 1998). Although ambient $\mathrm{CO}_{2}$ levels $\left(415 \mu \mathrm{mol} \mathrm{mol}^{-1}\right)$ are acceptable for plant growth, enrichment is often necessary in indoor $\mathrm{CE}$ systems because a fully developed canopy can decrease the $\mathrm{CO}_{2}$ level to less than $200 \mu \mathrm{mol} \mathrm{mol}^{-1}$ (Bauerle, 1984; Both et al., 2017). $\mathrm{CO}_{2}$ enrichment to levels higher than the ambient conditions increases the yield and fruit quality of mature tomato plants (Calvert and Slack, 1975; Enoch et al., 1976; Nilsen et al., 1983; Fierro et al., 1994; Reinert et al., 1997; Li et al., 2007b; Khan et al., 2013; Mamatha et al., 2014; Pan et al., 2019). Although many studies have focused on the benefits of individual factors (light or $\mathrm{CO}_{2}$ ), fewer studies have highlighted the beneficial interaction of supplemental light and $\mathrm{CO}_{2}$ enrichment (Labeke and Dambre, 1998; Naing et al., 2016; Ting et al., 2017; Pan et al., 2019). Furthermore, prior studies have also suggested that high $\mathrm{CO}_{2}$ levels could partially compensate for a lower PPFD through comparable growth and dry mass (Mortensen and Moe, 1983) by increasing the net photosynthetic rate (Bencze et al., 2011; Ting et al., 2017).

Research reports have shown an increase in net photosynthetic rate and growth at $\mathrm{CO}_{2}$ enrichment concentrations of 700$900 \mu \mathrm{mol} \mathrm{mol}^{-1}$ and suggested that higher concentrations provide little improvement in growth (Behboudian and Lai, 1994; Fierro et al., 1994; Mamatha et al., 2014; Zheng et al., 2019). However, we hypothesize that $\mathrm{CO}_{2}$ enrichment above recommended values will have a significant positive impact in tomato seedlings' net photosynthetic rate, growth, morphology due to: (1) seedlings are on the exponential growth stage with no competition; (2) the seedlings have a short growing period; and (3) $\mathrm{CO}_{2}$ enrichment is provided under relatively low DLI. Seedlings under optimal growing conditions show exponential growth. Once plants increase in size and plant competition is 
evident (canopy closure), the exponential growth phase changes to linear growth (Kirschbaum, 2011). During the exponential growth phase, plants show greater responses to high $\mathrm{CO}_{2}$ concentrations (Monje and Bugbee, 1998; Lewis et al., 2002). In the present study, tomato seedlings are in the exponential growth phase with no plant-to-plant competition. Research has also demonstrated long term adaptation to elevated $\mathrm{CO}_{2}$ concentration, including photosynthetic acclimation and leaf anatomy changes (i.e., lower stomatal density and conductance; Ziska et al., 1995; Zheng et al., 2019). However, these changes often take several days to occur (Ziska et al., 1995). Tomato seedlings in the present study were grown for 16-18 days (to the grafting stage) and 10-11 days from cotyledon expansion, which reduces the time for long term anatomical adaptation and photosynthetic acclimation to high $\mathrm{CO}_{2}$. Studies have shown down-regulation of photosynthesis under elevated $\mathrm{CO}_{2}$ (Kirschbaum, 2011). Studies have also shown that the downregulation of photosynthetic rate under high $\mathrm{CO}_{2}$ concentrations can be affected by the DLI of the previous day (Bunce and Sicher, 2003), where high DLI in the previous day has a down-regulation effect on the following day, while lower DLI on the previous day does not. Young tomato seedlings in the present study were grown under constant relatively low DLI and therefore the down-regulation effect of previous day is minimized.

In the present study, the first objective was to study the effects of $\mathrm{CO}_{2}$ enrichment with DLI level of $6.5,9.7$, or $13.0 \mathrm{~mol}$ $\mathrm{m}^{-2} \mathrm{~d}^{-1}$ (relatively low PPFD of $100-200 \mu \mathrm{mol} \mathrm{m}^{-2} \mathrm{~s}^{-1}$ ) on the production of tomato seedlings. The second objective was to determine whether $\mathrm{CO}_{2}$ enrichment can maintain desirable plant growth under reduced light levels while maintaining comparable energy consumption, production cost, and highquality seedlings. The third objective was to determine whether $\mathrm{CO}_{2}$ enrichment can reduce the production time of tomato transplants through an increased growth rate. In addition, calculations of the costs associated with different DLI and $\mathrm{CO}_{2}$ combinations were also performed and compared.

\section{MATERIALS AND METHODS}

\section{Plant Material and Growing Conditions}

Four tomato cultivars were selected for this study: (1) "Rebelski" (Solanum lycopersicum; De Ruiter Seeds, Bergschenhoek, Netherlands), a popular indeterminate variety used in high tunnels and greenhouses for fresh-market tomatoes; (2) "Florida47 R" (Solanum lycopersicum; Seminis Vegetable Seeds, St. Louis, MO, United States), a determinate variety used for field production; (3) "Maxifort" (Solanum lycopersicum x Solanum habrochaites; De Ruiter Seeds, Bergschenhoek, Netherlands), a vigorous rootstock that confers resistance to multiple soil-borne pathogens; and (4) "Shin Cheong Gang" (Solanum lycopersicum; De Ruiter Seeds, Bergschenhoek, Netherlands), an option for growers needing plants with disease resistance specifically against Fusarium race 3 and bacterial wilt. The seeds were sown in trays of Grodan Kiem rockwool plugs $(27 \times 20 \mathrm{~mm}$; Grodan, Delta, Canada), and one seed was planted per cell at a density of 1000 plants $\mathrm{m}^{-2}$. The seeds were covered with vermiculite, and the trays were sub-irrigated until full saturation. Following irrigation, the trays were placed into a germination chamber at $28^{\circ} \mathrm{C}$ under darkness. Once radical emergence was evident (24-48 $\mathrm{h}$ depending on the cultivar), the trays were moved into three growth chambers subjected to the respective treatments. The temperature was set to $24^{\circ} \mathrm{C}$ during the day and $16^{\circ} \mathrm{C}$ at night to obtain a daily temperature average of $22^{\circ} \mathrm{C}$. The relative humidity $(\mathrm{RH})$ was maintained at $50-55 \%$ in all the treatments. The temperature and $\mathrm{RH}$ were monitored and logged every minute ( $\mathrm{HOBO}$ onset UX100-023, Onset Computer Corporation, Bourne, MA, United States) during the experiment, and a summary is presented in Table 1. Dehumidifiers were included in each chamber to help manage the humidity. The plants were watered manually by sub-irrigating the trays twice daily using a nutrient solution composed of $90 \mathrm{mg} \mathrm{L}^{-1} \mathrm{~N}, 47 \mathrm{mg}$ $\mathrm{L}^{-1} \mathrm{P}, 144 \mathrm{mg} \mathrm{L}^{-1} \mathrm{~K}, 160 \mathrm{mg} \mathrm{L}^{-1} \mathrm{Ca}, 60 \mathrm{mg} \mathrm{L}^{-1} \mathrm{Mg}, 113 \mathrm{mg}$ $\mathrm{L}^{-1} \mathrm{~S}, 105 \mathrm{mg} \mathrm{L}^{-1} \mathrm{Cl}$, and micronutrients (Jensen and Malter, 1995). The EC and $\mathrm{pH}$ of the nutrient solution were recorded daily (Hanna Instruments, Limena, Italy; Table 1).

\section{$\mathrm{CO}_{2}$ Treatments}

Three separate growth chambers had different $\mathrm{CO}_{2}$ level set points of $448 \pm 32$ (400-ambient), $1010 \pm 45$ (1000), and $1568 \pm 129(1600) \mu \mathrm{mol} \mathrm{mol}^{-1}$. The chambers were of identical size (width of $2.4 \mathrm{~m}$, depth of $1.2 \mathrm{~m}$, and height of $2.1 \mathrm{~m}$ ) and had identical controls. The $\mathrm{CO}_{2}$ level was logged every minute and monitored (Viasala GMW115, Vantaa, Finland) to maintain sufficient levels (Table 1). During the dark period, all the chambers were ventilated to return the $\mathrm{CO}_{2}$ concentration to the ambient level of $\sim 400 \mu \mathrm{mol} \mathrm{mol}{ }^{-1}$. The chambers used for the treatments were randomized before each of the three repeated experiments.

\section{Light Quality and Intensity}

Research has suggested that the best spectral quality for producing a tomato transplant is a blue:red ratio of 1:1 (Liu et al., 2011; Hernández et al., 2016). This ratio results in an increased photosynthetic rate (Kim et al., 2004; Li et al., 2007b; Liu et al., 2011), high plant compactness, and high fresh and dry masses (Hernández et al., 2016). However, some cultivars of tomato rootstocks have shown susceptibility to intumescence when grown under conditions lacking UV-B (Lang and Tibbitts, 1983; Craver, 2014). Further research has indicated that the inclusion of end-of-day far-red (EOD-FR) treatment combined with a spectrum of high blue PFD can be an effective strategy to mitigate intumescence (Eguchi et al., 2016). In addition, EODFR treatment also increases the hypocotyl length of tomato seedlings, which is desirable for tomato grafting (Chia and Kubota, 2010). With respect to EOD-FR treatment, research has shown that the saturation dose for hypocotyl extension and intumescence reduction is $5 \mathrm{mmol} \mathrm{m} \mathrm{m}^{-2} \mathrm{~d}^{-1}$, which can be achieved by exposure to $3.5 \mu \mathrm{mol} \mathrm{m}{ }^{-2} \mathrm{~s}^{-1}$ for $24 \mathrm{~min}$ (Chia and Kubota, 2010; Eguchi et al., 2016). The LED fixtures used in this study (GE ARIZE, GEHL48HPPB1, GE Current, Boston, MA, United States) comprised a $42 \%$ blue (B) and $58 \%$ red (R) photon flux (PFD; close to the recommended 1B:1R ratio) with peaks at $448 \mathrm{~nm}(\mathrm{~B})$ and $662 \mathrm{~nm}(\mathrm{R})$, both with a full 


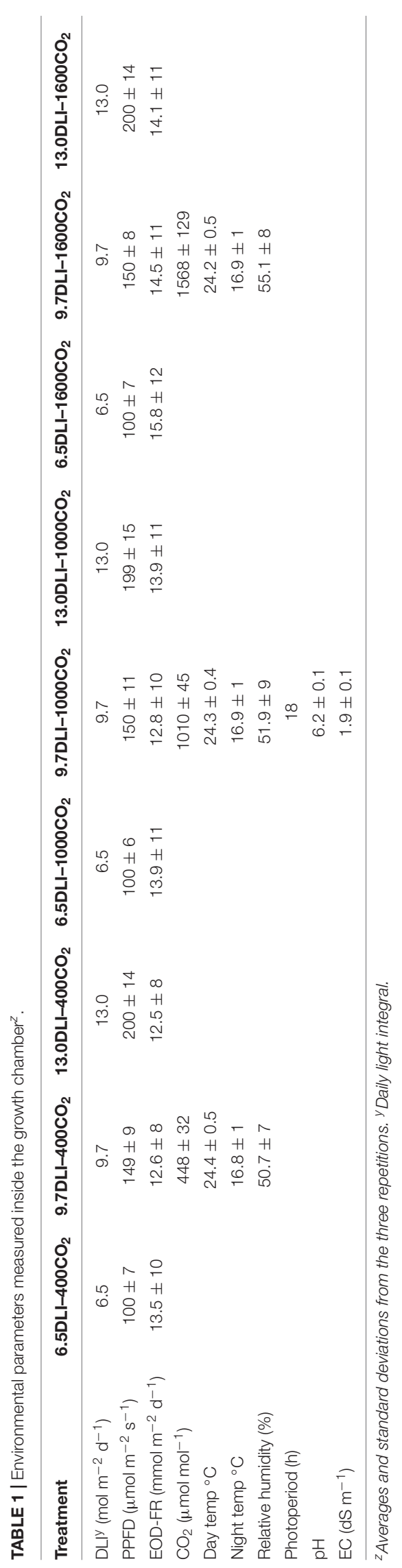

width at half maximum (FWHM) value of $18 \mathrm{~nm}$ (Figure 1). Fixtures were installed inside each chamber to produce three light levels, namely, 100, 150, and $200 \mu \mathrm{mol} \mathrm{m}^{-2} \mathrm{~s}^{-1}$ PPFD, with an 18-h photoperiod.

The treatments within the chamber were separated from each other to ensure that the LED beam angle did not interfere with the other treatments. Light maps were produced for each treatment to ensure that the treatments exhibited minimal variation within each light intensity. The fixtures were set to an 18-h photoperiod (06:00-0:00) to provide three DLI treatments of $6.5,9.7$, and $13.0 \mathrm{~mol} \mathrm{~m}^{-2} \mathrm{~d}^{-1}$ for 100,150 , and $200 \mu \mathrm{mol} \mathrm{m} \mathrm{m}^{-2} \mathrm{~s}^{-1}$ PPFD, respectively (Table 1). EODFR treatment at $7.6 \mu \mathrm{mol} \mathrm{m}{ }^{-2} \mathrm{~s}^{-1} \mathrm{PF}$ with a peak at $737 \mathrm{~nm}$ with a FWHM of $29 \mathrm{~nm}$ (Phillips Greenpower LED Research Module Far Red, 929000632103, Amsterdam, Netherlands) was provided evenly to all the treatments for $30 \mathrm{~min}$ after the end of the photoperiod (0:00-0:30). The average EOD-FR dosage per treatment is presented in Table $\mathbf{1}$ and is above the saturation point. The photoperiodic and EOD lighting was measured with a spectroradiometer (PS-300, Apogee instruments, Logan, UT, United States) before and after each experimental run to measure the quality and quantity of PFD. The light measurements were averaged from eight locations from each treatment and are shown in Table 1. Height adjustable lights and growing tables were installed to maintain the same PFD at the top of the canopy throughout the experiment. To account for variations in the light gradient within a light treatment, the trays were systematically rotated daily.

\section{Measurement and Experimental Design}

To track the growth of the stem diameter, total height, and leaf count, daily measurements were obtained from a subsample of 15 plants subjected to each treatment starting at day 10 until the final data collection. Commercially, tomato seedlings are typically spaced out (lower plant density) or grafted when plants reach canopy closure $(\sim 3$ true leaves and stem diameter of $1.8 \mathrm{~mm})$. Therefore, a stem diameter of $1.8 \mathrm{~mm}$ was used as a threshold for data collection. Destructive data collections were performed when the last treatment reached a stem diameter of $1.8 \mathrm{~mm}$. Averages from the subsamples of each experimental replication were obtained. The measurements included the stem diameter, hypocotyl length, epicotyl length, total height, leaf number, and fresh mass. The stem diameter was measured using a caliper (Mitutoyo Absolute Digimatic Caliper, Aurora, IL, United States), and the hypocotyl, epicotyl, and total heights were measured with a ruler. The number of leaves above a $1-\mathrm{cm}$ threshold was counted, and the leaf area, including that of leaves greater than $1 \mathrm{~cm}$, was also recorded using a leaf area meter (LI-3100, LICOR Biosciences, Lincoln, NE, United States). Fresh samples were dried at $70^{\circ} \mathrm{C}$ and then weighed to record the dry mass.

The chlorophyll concentration was quantified as described by Moran and Porath (1980): two $56.6-\mathrm{mm}^{2}$ leaf disks were cut from each plant of three subsamples per treatment per repetition. The gas exchange was measured at the end of the experiment using a portable photosynthesis machine (LI-6800, LI-COR Biosciences, Lincoln, NE, United States), and the results from three subsamples from each treatment were averaged. 

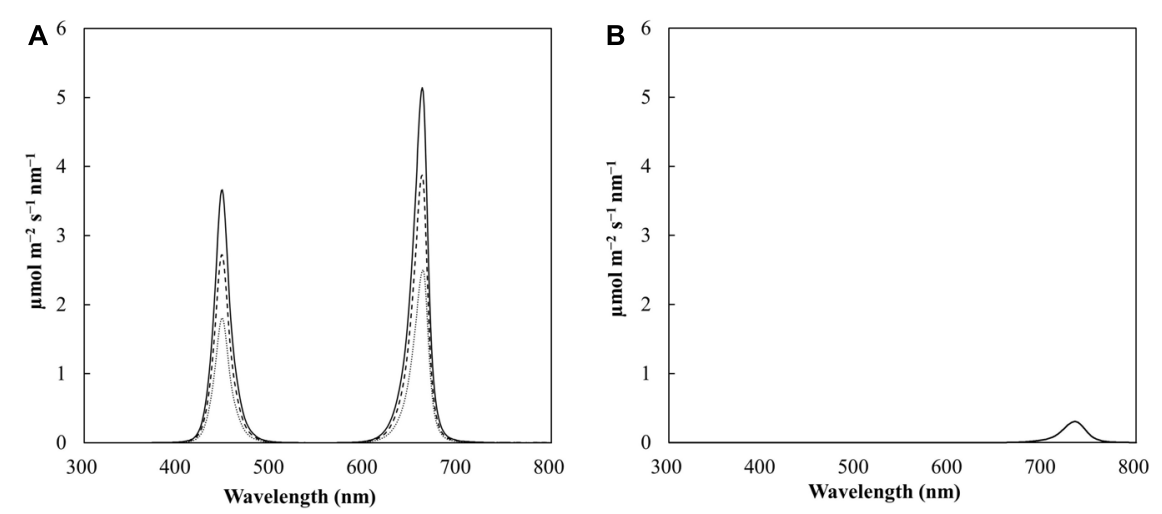

FIGURE 1 | Spectral scan of the photoperiod at light intensities of 100 (dotted line), 150 (dashed line), and 200 (solid line) $\mu \mathrm{mol} \mathrm{m}^{-2} \mathrm{~s}^{-1}$ (A) and spectral scan of the end of day (EOD) treatment $\left(5 \mathrm{mmol} \mathrm{m} \mathrm{m}^{-2} \mathrm{~d}^{-1}\right)$; (B) during the experiment. The data are averaged across the treatments. The photoperiod was 18 $\mathrm{h}(06: 00-0: 00)$, and the EOD-far-red (FR) treatment was delivered for 30 min (0:00-0:30).

Measurements were performed on the youngest fully expanded leaf for all treatments and tomato cultivars. Environmental conditions for the measurements were $22^{\circ} \mathrm{C}, 60 \% \mathrm{RH}$ and light levels and $\mathrm{CO}_{2}$ concentrations that matched the light and $\mathrm{CO}_{2}$ treatments (Table 1).

Statistical analyses were conducted to compare the treatments using JMP software 14.2 (SAS Institute, Cary, NC, United States). The experimental design was a split-plot design, the $\mathrm{CO}_{2}$ treatments were in different climate rooms and the three light levels were in each $\mathrm{CO}_{2}$ climate room. Light levels were randomized in each climate room for each of the three independent experiments. Also, climate rooms were randomized for each $\mathrm{CO}_{2}$ treatment at each of the three independent experiments. The treatment effects were run by cultivar and all cultivars had the same treatment response; therefore, the data for all cultivars was combined.

Linear regression was applied to the quantitative response to increasing the DLI at each $\mathrm{CO}_{2}$ concentration (all measured parameters) and to increasing $\mathrm{CO}_{2}$ for each DLI level (dry mass). To compare the slopes of the linear fit, a GLM procedure with Indicator Parameterization Estimates was used. Analysis of variance and mean separations via the Tukey-Kramer HSD test (alpha $=0.05$ ) were computed when comparing the different $\mathrm{CO}_{2}$ treatments within each light level (Figure 3). Dunnett's test was used to compare the treatments with different DLI and $\mathrm{CO}_{2}$ conditions to the $13.0 \mathrm{DLI}-400 \mathrm{CO}_{2}$ control treatment. The experiment was conducted three times.

\section{Evaluation of the Cost of Electrical Lighting and $\mathrm{CO}_{2}$ Enrichment}

A summary of the variables, values, and units for the following calculations is shown in Table 2.

The number of fixtures needed $(\mathrm{N})$ to reach a set intensity can be described by Eq. (1) adapted from Aldrich and Bartock (1994), where PPFD is the desired PPFD $\left(100,150\right.$, or $200 \mu \mathrm{mol} \mathrm{m}^{-2} \mathrm{~s}^{-1}$ in our experiment), $\mathrm{A}$ is the total growing area (length $\times$ width; $1 \mathrm{~m}^{2}$ for ease of calculation), UF is the utilization factor [value that considers the beam angle distribution, growing area geometry, and reflectivity; 0.9 based on the information reported by Hernández and Kubota (2015)], MF is the maintenance factor [decrease in the fixture photon output over time; 0.9 based on the information reported by Hernández and Kubota (2015)], LPE is the lighting photon efficiency based on current technology (3.0 $\mu \mathrm{mol} \mathrm{J})^{-1}$ or $\mu \mathrm{mol} \mathrm{W} \mathrm{W}^{-1} \mathrm{~s}^{-1}$; GE current, Boston, MA, United States), and WF is the wattage required to power each fixture $(30.5 \mathrm{~W})$.

$$
\mathrm{N}=\frac{\mathrm{PPFD} \times \mathrm{A}}{\mathrm{LPE} \times \mathrm{WF} \times \mathrm{UF} \times \mathrm{MF}}
$$

The area electric power consumption (APC; $\mathrm{W} \mathrm{m}^{-2}$ ) of lamps can be expressed by an Eq. (2) Hernández and Kubota (2015), which does not include the cost of HVAC cooling:

$$
\mathrm{APC}=\frac{\mathrm{N} \times \mathrm{WF}}{\mathrm{A}}
$$

The daily electrical cost (DEC; $\$ \mathrm{~d}^{-1} \mathrm{~m}^{-2}$ ) can be expressed with Eq. (3), where APC (2) is multiplied by the photoperiod (P; h), divided by 1000 to convert from $\mathrm{W}$ h to $\mathrm{kW}$ h and then multiplied by the electricity rate $\mathrm{Er}\left(\$ \mathrm{kWh}^{-1}\right)$, which varies by region. In this study, a rate of $\$ 0.09$ was used based on the average in the United States (Lewis et al., 2014).

$$
\mathrm{DEC}=\frac{\mathrm{APC} \times \mathrm{P}}{1000} \times \mathrm{Er}
$$

The final calculation was the total electricity cost (TEC; $\$ \mathrm{~m}^{-2}$ ), which is expressed by Eq. (4), where DEC is multiplied by the duration (D) to reach canopy closure and stem diameter of $1.8 \mathrm{~mm}$ (15-18 days depending on the cultivar and treatments used in this experiment).

$$
\mathrm{TEC}=\mathrm{DEC} \times \mathrm{D}
$$

The usage of $\mathrm{CO}_{2}\left(\mathrm{~B} ; \mathrm{kg} \mathrm{CO} \mathrm{d}^{-1}\right)$ can be described by Eq. (5; Ohyama and Kozai, 1998), where $\left(\mathrm{P}_{\mathrm{n}}\right)$ is the $\mathrm{CO}_{2}$ level per square meter of transplant growing area per hour $\left(\mathrm{kg} \mathrm{CO}_{2} \mathrm{~m}^{-2} \mathrm{~h}^{-1}\right)$, which was calculated based on the measured photosynthetic 
TABLE 2 | Symbols, descriptions, values, and units used in the calculations.

\begin{tabular}{|c|c|c|c|}
\hline Symbol & Description & Value & Unit \\
\hline A & Total growing area & 1 & $m^{2}$ \\
\hline APC & $\begin{array}{l}\text { Areal electric power } \\
\text { consumption }\end{array}$ & $41.2-82.3$ & $\mathrm{~W} \mathrm{~m}^{-2}$ \\
\hline$B$ & Usage of $\mathrm{CO}_{2}$ per day & $0.020-0.057$ & $\mathrm{~kg} \mathrm{CO}_{2} \mathrm{~d}^{-1}$ \\
\hline $\mathrm{CC}$ & Cost of $\mathrm{CO}_{2}$ & 0.58 & $\$ \mathrm{~kg}^{-1}$ \\
\hline $\mathrm{C}_{\text {in }}$ & $\begin{array}{l}\mathrm{CO}_{2} \text { concentration inside the } \\
\text { chamber }\end{array}$ & $0.0004-0.0016$ & $\mathrm{~mol} \mathrm{~mol}{ }^{-1}$ \\
\hline $\mathrm{C}_{\text {out }}$ & $\begin{array}{l}\mathrm{CO}_{2} \text { concentration outside the } \\
\text { chamber }\end{array}$ & 0.0004 & $\mathrm{~mol} \mathrm{~mol}{ }^{-1}$ \\
\hline D & Growing days per cycle & $15-18$ & $d$ \\
\hline DEC & Daily electrical cost & $0.07-0.13$ & $\$ d^{-1} m^{-2}$ \\
\hline DEN & Planting density & 1000 & plants $\mathrm{m}^{-2}$ \\
\hline$E$ & Air exchange rate & 0.10 & $h^{-1}$ \\
\hline$E_{r}$ & Electricity rate (United States) & 0.09 & $\$ \mathrm{kWh}$ \\
\hline $\mathrm{K}_{\mathrm{m}}$ & $\begin{array}{l}\text { Volume to mass conversion for } \\
\mathrm{CO}_{2}\left(22^{\circ} \mathrm{C}\right)\end{array}$ & 1.79 & $\mathrm{~kg} \mathrm{CO}_{2} \mathrm{~m}^{-3}$ \\
\hline LPE & Lighting photon efficacy & 3.0 & $\mu \mathrm{mol} \mathrm{J}^{-1}$ \\
\hline MF & Maintenance factor & 0.90 & - \\
\hline $\mathrm{N}$ & Number of lamps & $1.3-2.7$ & lamps $\mathrm{m}^{-2}$ \\
\hline$P_{n}$ & Net photosynthetic rate per LAl & $0.001-0.003$ & $\mathrm{~kg} \mathrm{~m}^{-2} \mathrm{~h}^{-1}$ \\
\hline$P$ & Photoperiod & 18 & $\mathrm{~h}$ \\
\hline$\llcorner A \mathrm{I}$ & Leaf area index & 1.9 & $m^{2} m^{-2}$ \\
\hline PPC & Per plant cost & $0.0014-0.0026$ & $\$$ \\
\hline PPFD & $\begin{array}{l}\text { Photosynthetic photon flux } \\
\text { density }\end{array}$ & $100-200$ & $\mu \mathrm{mol} \mathrm{m} \mathrm{m}^{-2} \mathrm{~s}^{-1}$ \\
\hline TCC & $\begin{array}{l}\text { Total } \mathrm{CO}_{2} \text { cost per production } \\
\text { cycle }\end{array}$ & $0.21-0.50$ & $\$ m^{-2}$ \\
\hline TEC & $\begin{array}{l}\text { Total electricity cost per } \\
\text { production cycle }\end{array}$ & $1.13-2.26$ & $\$ m^{-2}$ \\
\hline UF & Utilization factor & 0.90 & - \\
\hline V & Volume of growing facility & 1 & $m^{3}$ \\
\hline WF & Wattage per fixture & 30.5 & W \\
\hline
\end{tabular}

rate for each treatment combination using the youngest fully expanded leaf. The single leaf photosynthesis measurements $\left(\mu \mathrm{mol} \mathrm{m} \mathrm{m}^{-2} \mathrm{~s}^{-1}\right.$ ) were extrapolated to photosynthetic rate per meter square area using total leaf area per plant $\left(19 \mathrm{~cm}^{2}\right)$, plant density of 1000 plants $\mathrm{m}^{-2}$, photoperiod of $18 \mathrm{~h}$, and the final LAI (Pn: 3.7-9.8 $\mu \mathrm{mol} \mathrm{m}^{-2} \mathrm{~s}^{-1}$; LAI: 1.9). The other components of the equation include the following: $\mathrm{K}_{\mathrm{m}}$ is the conversion factor from volume to mass for $\mathrm{CO}_{2}\left(1.79 \mathrm{~kg} \mathrm{CO}_{2} \mathrm{~m}^{-3}\right.$, at $\left.22^{\circ} \mathrm{C}\right)$, $\mathrm{E}$ is the number of air exchanges per hour $\left(0.1 \mathrm{~h}^{-1}\right)$ which is considered an upper level exchange rate for enclosed controlled environments (0.001-0.1 $\mathrm{h}^{-1}$; Ohyama and Kozai, 1998), V is the volume of the growing area ( $1 \mathrm{~m}^{3}$ for ease of calculation), $\mathrm{C}_{\text {in }}$ is the desired setpoint $\mathrm{CO}_{2}$ concentration inside the facility, which varies between 400 and $1600 \mu \mathrm{mol} \mathrm{mol}^{-1}$ (0.0004$0.0016 \mathrm{~mol} \mathrm{~mol}^{-1}$ ) depending on the treatment, and $\mathrm{C}_{\text {out }}$ is the $\mathrm{CO}_{2}$ level outside the facility, which is typically near ambient levels $\left(0.0004 \mathrm{~mol} \mathrm{~mol}^{-1}\right)$. Pp represents the photoperiod $(18 \mathrm{~h})$.

$$
\mathrm{B}=\left(\mathrm{A} \times \mathrm{P}_{\mathrm{n}}+\mathrm{K}_{\mathrm{m}} \times \mathrm{E} \times \mathrm{V}\left(\mathrm{C}_{\mathrm{in}}-\mathrm{C}_{\text {out }}\right)\right) \times \mathrm{P}_{\mathrm{p}}
$$

The total $\mathrm{CO}_{2}$ cost (TCC; $\$ \mathrm{~m}^{-2}$ ) is expressed by Eq. (6). As described in the equation, $\mathrm{B}\left(\mathrm{kg} \mathrm{CO} \mathrm{Cd}^{-1}\right.$, affected by the $\mathrm{CO}_{2}$ level, and PPFD) is multiplied by $\mathrm{D}$ (15-18 days depending on the treatments used in this experiment) and multiplied by the cost of $\mathrm{CO}_{2}$ (CC, $\$ 0.58$ per kg, small volume price, Airgas, Radner, PA, United States).

$$
\mathrm{TCC}=\mathrm{B} \times \mathrm{D} \times \mathrm{CC}
$$

The total production cost per square meter $\left(\mathrm{PPC} ; \$ \mathrm{~m}^{-2}\right.$ ) can then be described by Eq. (7), which involves the addition of TEC $\left(\$ \mathrm{~m}^{-2} ; 4\right)$ and TCC $\left(\$ \mathrm{~m}^{-2} ; 6\right)$ :

$$
\mathrm{PPC}=\mathrm{TEC}+\mathrm{TCC}
$$

\section{RESULTS AND DISCUSSION}

\section{Plant Growth (Fresh and Dry Masses and Net Photosynthetic Rate)}

For all light treatments, the fresh mass increased linearly with increases in the DLI for each level of $\mathrm{CO}_{2}$ (Figure 2A). $\mathrm{CO}_{2}$ enrichment to $1000 \mu \mathrm{mol} \mathrm{mol}^{-1}$ and $1600 \mu \mathrm{mol} \mathrm{mol}^{-1}$ resulted in the same rate of increase (slope) in the fresh mass as that obtained with increasing the DLI, and higher rates of increase in the fresh mass with increases in the DLI were observed under $\mathrm{CO}_{2}$-enriched conditions to $1600 \mu \mathrm{mol} \mathrm{mol}^{-1}$ than at $400 \mu \mathrm{mol}$ $\mathrm{mol}^{-1}$ (Figure 2A). In general, under all $\mathrm{CO}_{2}$ treatments, the fresh mass increased by $16 \%$ with an increase in the DLI from 6.5 to $13.0 \mathrm{~mol} \mathrm{~m}^{-2} \mathrm{~d}^{-1}$. On average, under all DLI treatments, the fresh mass increased by $20 \%$ after $\mathrm{CO}_{2}$ enrichment to $1600 \mu \mathrm{mol}$ $\mathrm{mol}^{-1}$ from $400 \mu \mathrm{mol} \mathrm{mol}^{-1}$. The combination of increasing the DLI from $6.5 \mathrm{~mol} \mathrm{~m}^{-2} \mathrm{~d}^{-1}$ to $13.0 \mathrm{~mol} \mathrm{~m}^{-2} \mathrm{~d}^{-1}$ and $\mathrm{CO}_{2}$ enrichment from $400 \mu \mathrm{mol} \mathrm{mol}{ }^{-1}$ to $1600 \mu \mathrm{mol} \mathrm{mol}{ }^{-1}$ increased the fresh mass by $36 \%$.

Previous research studies on transplants have shown the impact of increasing the DLI on the fresh mass (Fan et al., 2013; Hernández and Kubota, 2014; Garcia and Lopez, 2020; Xu and Hernández, 2020). For example, Fan et al. (2013) showed a $27 \%$ increase in the fresh mass of tomato seedlings when the DLI was increased from 6.5 to $13.0 \mathrm{~mol} \mathrm{~m}^{-2} \mathrm{~d}^{-1}$ under LEDs (50B:50R, $12 \mathrm{~h}$ photoperiod) in a growth chamber. In a study of tomato, pepper, and cucumber transplants, Garcia and Lopez (2020) found fresh mass increases of 17,33 , and $18 \%$, respectively, when the DLI was increased from 6.1 to $11.8 \mathrm{~mol} \mathrm{~m}^{-2} \mathrm{~d}^{-1}$ using supplemental high-pressure sodium (HPS) lighting in a greenhouse. In addition, Hernández and Kubota (2014) found a $28 \%$ increase in the fresh mass of cucumber seedlings when the DLI in a greenhouse was increased from 5.2 to $8.7 \mathrm{~mol} \mathrm{~m}^{-2} \mathrm{~d}^{-1}$ using supplemental LED lighting (0B:100R, 4B:96R, 16B:84R, and $18 \mathrm{~h}$ photoperiod).

The impacts of $\mathrm{CO}_{2}$ enrichment on the fresh mass of tomato seedlings have not been reported. However, many studies have demonstrated that $\mathrm{CO}_{2}$ enrichment increases the fresh fruit yield of tomato in a range of $19-124 \%$ when $\mathrm{CO}_{2}$ is increased to a range of 700-1400 $\mu \mathrm{mol} \mathrm{mol}^{-1}$ separately from that of supplemental lighting (Calvert and Slack, 1975; Nilsen et al., 1983; Reinert et al., 1997; Khan et al., 2013; Mamatha et al., 2014; Pan et al., 2019).

The dry mass increased linearly with increases in the DLI, and this finding was obtained with all light treatments (Figure 2B). 

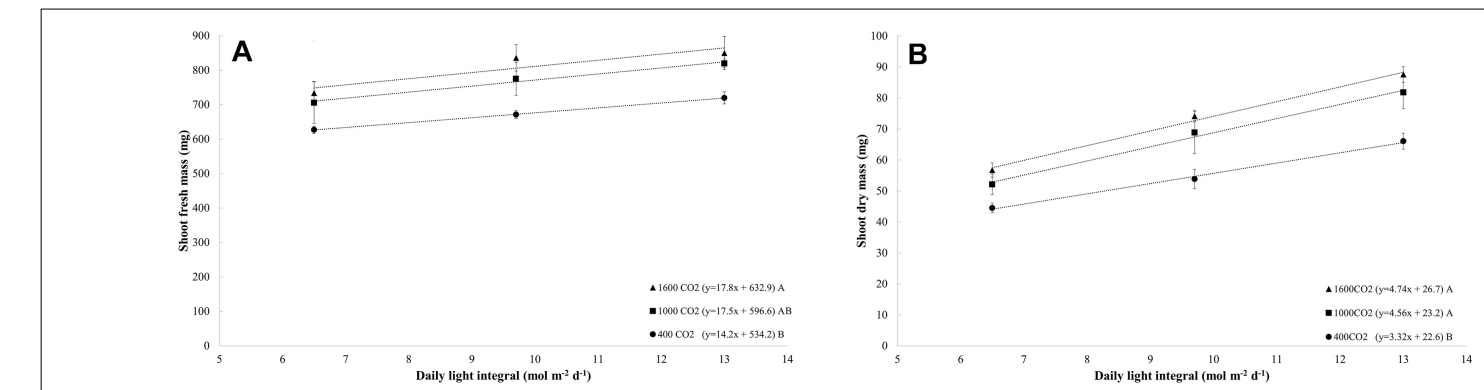

C

${ }^{60}$ D

${ }_{35}^{40}$ E

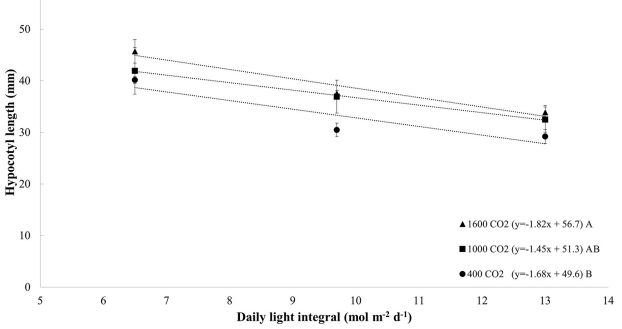

${ }^{25}$ G

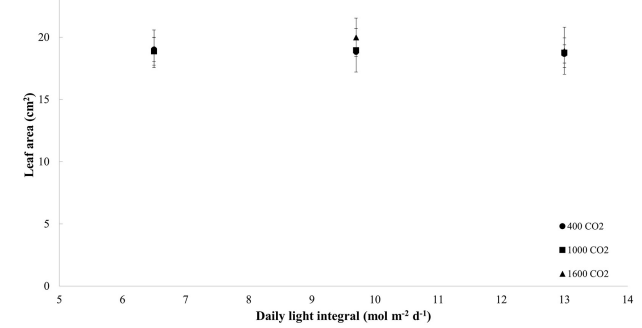

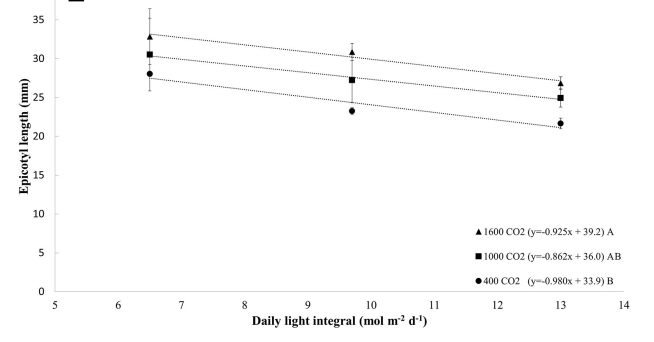

${ }^{4} \mathbf{H}$

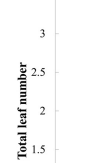

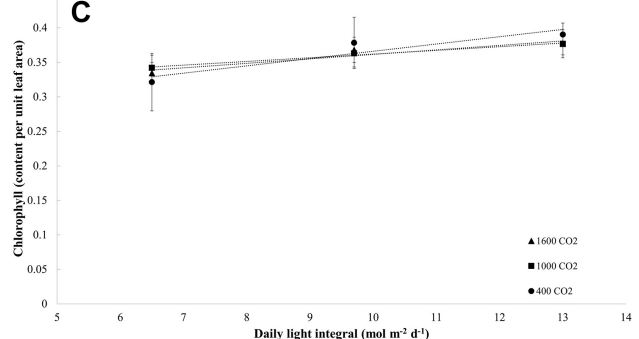

${ }^{90} \mathbf{F}$

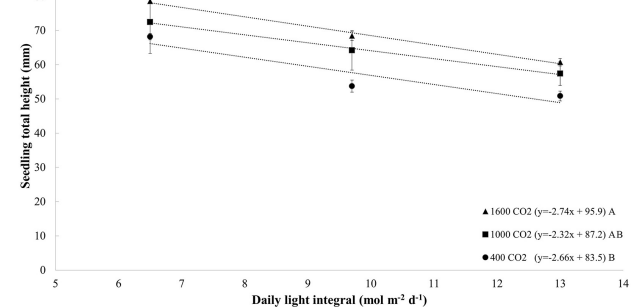

${ }^{2.6}[\mathbf{I}$

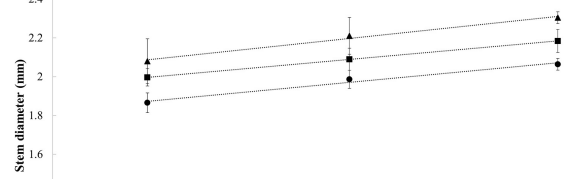

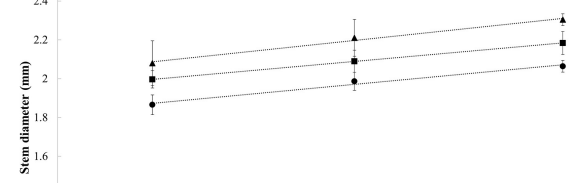

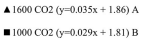

FIGURE 2 | (A-I) Effects of the daily light integrals (DLIs: 6.5, 9.7, and $13 \mathrm{~mol} \mathrm{~m}^{-2} \mathrm{~d}^{-1}$ ) and $\mathrm{CO}_{2}$ levels (400, 1000, and $1600 \mu$ mol mol-1 ${ }^{-1}$ ) on the morphology, physiology, and growth rate of four cultivars of tomato

(average of all cultivars) at day 18. The dotted lines represent significant linear regressions, and the equations are shown in parentheses. Different letters represent significant differences of the slopes. 
$\mathrm{CO}_{2}$ enrichment to $1000 \mu \mathrm{mol} \mathrm{mol}{ }^{-1}$ and $1600 \mu \mathrm{mol} \mathrm{mol}^{-1}$ resulted in the same rate of increase (slope) in the dry mass as that obtained with increases in the DLI, and both $\mathrm{CO}_{2}$-enriched levels resulted in a higher rate of increase (slope) in the dry mass with increases in the DLI compared with that found with a $\mathrm{CO}_{2}$ concentration of $400 \mu^{m o l ~ m o l}{ }^{-1}$ (slope; Figure 2B). Under all $\mathrm{CO}_{2}$ treatments, the dry mass increased by $53 \%$ when the DLI was increased from 6.5 to $13.0 \mathrm{~mol} \mathrm{~m}^{-2} \mathrm{~d}^{-1}$, whereas under all DLI treatments, the dry mass increased by $33 \%$ in response to enrichment to $1000-1600 \mu \mathrm{mol} \mathrm{mol}{ }^{-1}$ from $400 \mu \mathrm{mol} \mathrm{mol}^{-1}$. The simultaneous increase in the DLI from $6.5 \mathrm{~mol} \mathrm{~m}^{-2} \mathrm{~d}^{-1}$ to $13.0 \mathrm{~mol} \mathrm{~m}^{-2} \mathrm{~d}^{-1}$ and $\mathrm{CO}_{2}$ enrichment from $400 \mu \mathrm{mol} \mathrm{mol}^{-1}$ to $1600 \mu \mathrm{mol} \mathrm{mol}^{-1}$ increased the dry mass by $165 \%$.

When comparing dry mass plant response to $\mathrm{CO}_{2}$ enrichment (all light levels combined), the dry mass increased linearly with increases in the $\mathrm{CO}_{2}$ level $\left(y=0.02 \mathrm{x}+50.1 ; R^{2}=0.29\right.$; and $p=0.0008)$. However, when analyzing the responses by DLI (Figure 3), a trend is present that at higher DLI levels, the dry mass response to $\mathrm{CO}_{2}$ is reaching a saturation point while at lower DLI the response is linear. Research studies have shown similar response (Bencze et al., 2011; Ting et al., 2017).

The comparison of dry mass response per cumulative photon flux (Figure 4) showed that plants under $\mathrm{CO}_{2}$-enrichment (1000$1600 \mu \mathrm{mol} \mathrm{mol}^{-1}$ ) conditions produce $0.25-0.26$ grams of dry mass per mole of light $\left(\mathrm{g} \mathrm{mol}^{-1}\right)$, whereas $0.18 \mathrm{~g} \mathrm{~mol}^{-1}$ is obtained under ambient $\mathrm{CO}_{2}$ conditions, which indicates that $\mathrm{CO}_{2}$ enrichment results in a $38-44 \%$ increase in light efficiency $\left(\mathrm{g} \mathrm{mol}^{-1}\right)$.

Previous research on transplants have shown the impact of increasing the DLI on dry mass (Fierro et al., 1994; Pramuk and Runkle, 2005; Fan et al., 2013; Hernández and Kubota, 2014; Pan et al., 2019; Garcia and Lopez, 2020; $\mathrm{Xu}$ and Hernández, 2020). In tomato seedlings, Fan et al. (2013) found a dry mass increase of $51 \%$ when the DLI was increased from 6.5 to $13.0 \mathrm{~mol} \mathrm{~m}^{-2} \mathrm{~d}^{-1}$ under LEDs (50B:50R, $12 \mathrm{~h}$ photoperiod). In greenhouses, Hernández and Kubota (2014) found a $47 \%$ increase in the cucumber seedling dry mass when the DLI was increased from 5.2 to $8.7 \mathrm{~mol}$ $\mathrm{m}^{-2} \mathrm{~d}^{-1}$ under LEDs (0B:100R, 4B:96R, 16B:84R, and $18 \mathrm{~h}$ photoperiod). In addition, Garcia and Lopez (2020) found an increase in the dry masses of tomato, pepper, and cucumber transplants ranging from 107 to $183 \%$ when the DLI was increased from 6.1 to $11.8 \mathrm{~mol} \mathrm{~m}^{-2} \mathrm{~d}^{-1}$ using HPS lighting in a greenhouse.

Previous research on tomato has also shown the impact of $\mathrm{CO}_{2}$ enrichment on the dry mass (Behboudian and Lai, 1994; Fierro et al., 1994; Li et al., 2007a; Wang et al., 2009; Pan et al., 2019). For example, studies have focused on the impact of increasing the $\mathrm{CO}_{2}$ concentration from an ambient level to 700-800 $\mu \mathrm{mol}$ $\mathrm{mol}^{-1}$, and this enrichment results in an increase in the dry mass of tomato plants of $27 \%$ when grown under florescent lamps (135 PPFD, $12 \mathrm{~h}$ photoperiod; Wang et al., 2009). A similar impact was shown under ambient greenhouse conditions by increasing the $\mathrm{CO}_{2}$ concentration from an ambient level to 700-800 $\mu \mathrm{mol}$ $\mathrm{mol}^{-1}$ resulting in a $16-27 \%$ increase of dry mass (Behboudian and Lai, 1994; Pan et al., 2019).
The net photosynthetic rate increased linearly with increases in the PPFD, and this finding was obtained with all light treatments ( $p=0.005$; Figure 5). Similarly, the net photosynthetic rate also increased linearly with increases in the $\mathrm{CO}_{2}$ level $\left(y=0.002 \mathrm{x}+4.24 ; R^{2}=0.36\right.$; and $p=0.008$; data not shown). Plants exposed to a $\mathrm{CO}_{2}$ concentration of $1000 \mu \mathrm{mol} \mathrm{mol}{ }^{-1}$ exhibited a higher rate of increase in their photosynthetic rate per increase (slope) in the PPFD than plants grown at $400 \mu \mathrm{mol}$ $\mathrm{mol}^{-1}$ (Figure 5). In addition, $\mathrm{CO}_{2}$ enrichment to $1600 \mu \mathrm{mol}$ $\mathrm{mol}^{-1}$ was associated with a higher rate of increase in the photosynthetic rate per PPFD than those obtained with $\mathrm{CO}_{2}$ levels of 400 and $1000 \mu \mathrm{mol} \mathrm{mol}^{-1}$ (Figure 5). In general, under all $\mathrm{CO}_{2}$ treatments, the net photosynthesis increased by $66 \%$ with an increase in the PPFD from 100 to $200 \mu \mathrm{mol} \mathrm{m} \mathrm{m}^{-2} \mathrm{~s}^{-1}$. On average, under all PPFD levels, the photosynthesis rate increased by $52 \%$ in response to $\mathrm{CO}_{2}$ enrichment to $1600 \mu \mathrm{mol} \mathrm{mol}^{-1}$ from $400 \mu \mathrm{mol} \mathrm{mol}^{-1}$. The combination of increasing the PPFD from $100 \mu \mathrm{mol} \mathrm{m}^{-2} \mathrm{~s}^{-1}$ to $200 \mu \mathrm{mol} \mathrm{m}^{-2} \mathrm{~s}^{-1}$ and $\mathrm{CO}_{2}$ level from $400 \mu \mathrm{mol} \mathrm{mol}^{-1}$ to $1600 \mu \mathrm{mol} \mathrm{mol}{ }^{-1}$ increased the net photosynthesis rate by $165 \%$.

Previous studies with transplants have shown that increasing the PPFD and $\mathrm{CO}_{2}$ concentration increases the photosynthetic rate (Fan et al., 2013; Hernández and Kubota, 2014; Lanoue et al., 2018; Pan et al., 2019). For example, tomato seedlings exhibit an increase in their photosynthetic rate of $90 \%$ when the PPFD is increased from 150 to $300 \mu \mathrm{mol} \mathrm{m} \mathrm{m}^{-2} \mathrm{~s}^{-1}$ (50B:50R, $12 \mathrm{~h}$ photoperiod; Fan et al., 2013). In greenhouse tomato transplant production, Pan et al. (2019) found a $21-39 \%$ increase in the photosynthetic rate with an increase in the PPFD of $200 \mu \mathrm{mol}$ $\mathrm{m}^{-2} \mathrm{~s}^{-1}$ with HPS lighting. With cucumber transplants, a 20\% increase in the photosynthetic rate was observed when the PPFD was increased by $54 \mu \mathrm{mol} \mathrm{m} \mathrm{m}^{-2} \mathrm{~s}^{-1}$ in a greenhouse with supplemental LEDs (0B:100R, 4B:96R, 16B:84R, and $18 \mathrm{~h}$ photoperiod; Hernández and Kubota, 2014). In response to $\mathrm{CO}_{2}$ enrichment to $1000 \mu \mathrm{mol} \mathrm{mol}{ }^{-1}$ from $400 \mu \mathrm{mol} \mathrm{mol}^{-1}$, Lanoue et al. (2018) found a 52\% increase in the photosynthetic rate of tomato seedlings. Similarly, Pan et al. (2019) showed that the photosynthetic rate of tomato seedlings increased by $9-27 \%$ with the enrichment of $\mathrm{CO}_{2}$ to $800 \mu \mathrm{mol} \mathrm{mol}{ }^{-1}$ from $400 \mu \mathrm{mol}$ $\mathrm{mol}^{-1}$.

In the present study, increasing the PPFD and $\mathrm{CO}_{2}$ concentrations increased the net photosynthetic rate and consequently resulted in more growth (increases in fresh and dry mass). In general, the plant responses to increases in the PPFD follow a logarithmic curve: increases in photosynthesis are observed until a saturation point is reached (Lopez and Runkle, 2017; Eichhorn-Bilodeau et al., 2019), and after this light saturation point, photosynthesis no longer increases with increases in the PPFD due to limitations of the Calvin cycle (Lopez and Runkle, 2017), and more specifically the enzyme activity and concentration of Rubisco (Bjorkman, 1981; Sukenik et al., 1987; Rivkin, 1990; Orellana and Perry, 1992; Geider and McIntyre, 2002). At the seedling stage of tomato, the saturation point for PPFD has been reported to be approximately $1200 \mu \mathrm{mol}$ $\mathrm{m}^{2} \mathrm{~s}^{-1}$; however, this saturation point is affected by other conditions, including the $\mathrm{CO}_{2}$ level (Ting et al., 2017). In our 


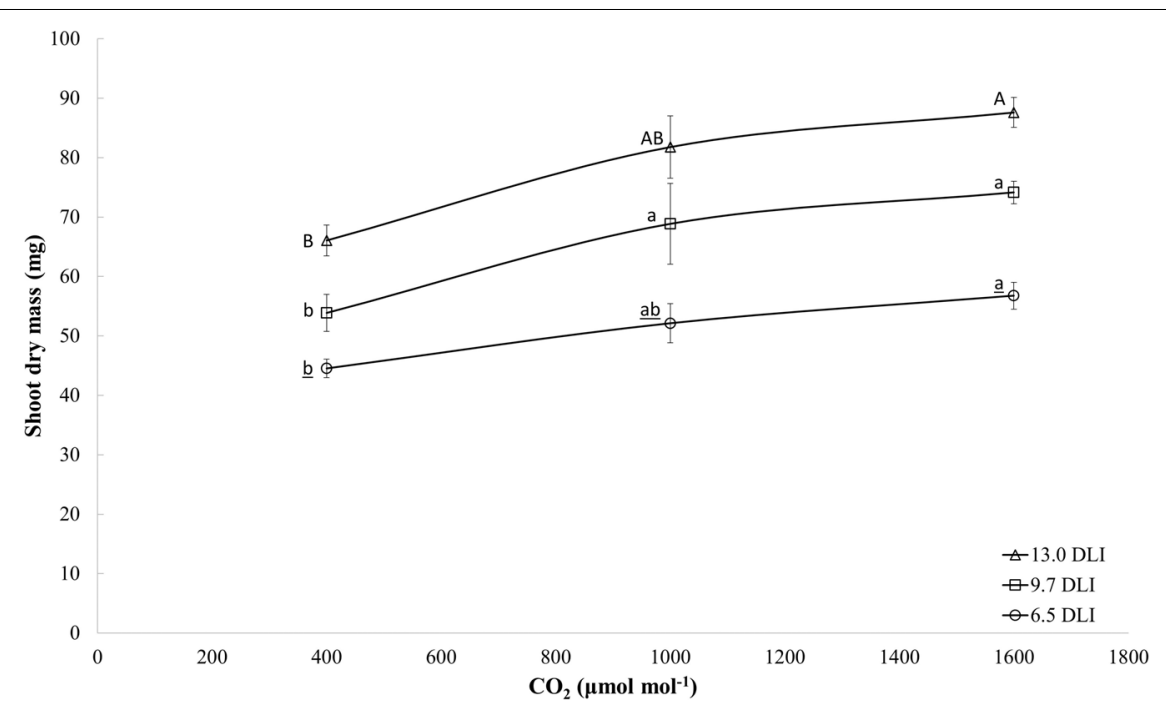

FIGURE 3 | Effects of the $\mathrm{CO}_{2}$ enrichment treatments $\left(400,1000,1600 \mu \mathrm{mol} \mathrm{mol}^{-1}\right.$ ) and light levels (DLIs: $6.5,9.7$, and 13 mol m${ }^{-2} \mathrm{~d}^{-1}$ ) on dry mass of four cultivars of tomato (average of all cultivars) at day 18. The letters represent significant differences within each light level.

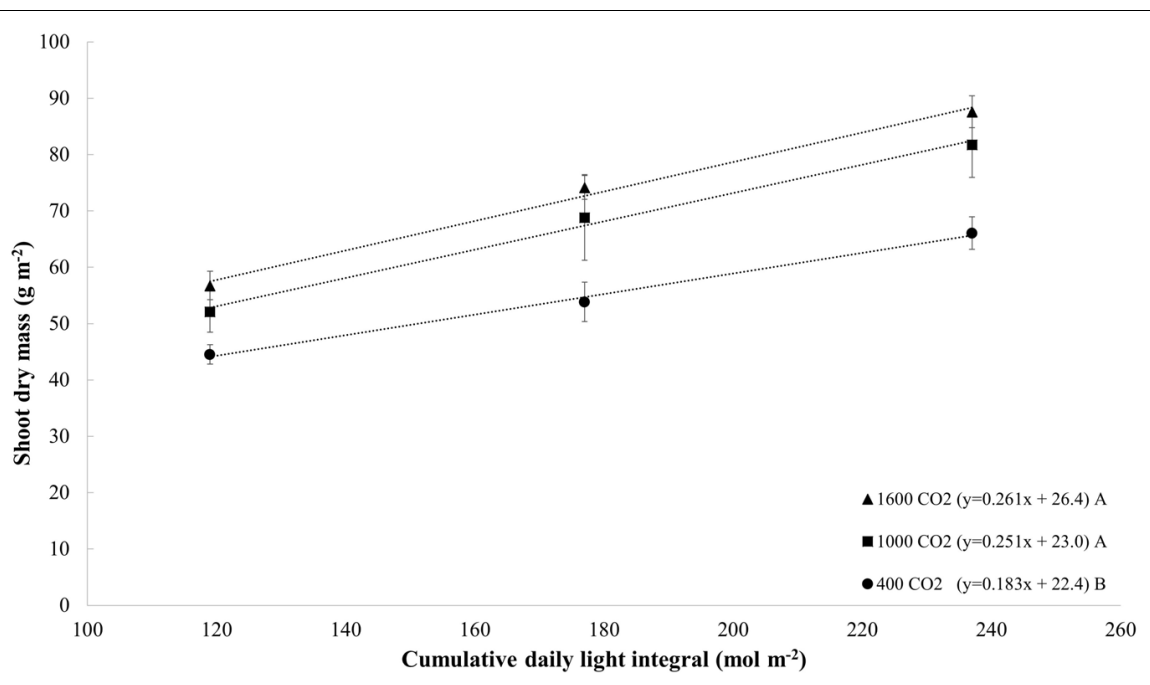

FIGURE 4 | Dry mass $\left(\mathrm{g} \mathrm{m}^{-2}\right.$ ) of tomato (all cultivars) grown with different cumulative photon flux (119, 177, and 237 mol m-2) and CO 2 levels (400, 1000 , and $\left.1600 \mu \mathrm{mol} \mathrm{mol}{ }^{-1}\right)$. The dotted lines represent significant linear regressions, and the equations are shown in parentheses. Different letters indicate significant differences of the slopes.

study of tomato seedlings, the PPFD levels used (100-200 $\mu \mathrm{mol}$ $\mathrm{m}^{-2} \mathrm{~s}^{-1}$ ) did not reach the light saturation point.

Similar to the PPFD, there is a saturation point regarding the benefits of $\mathrm{CO}_{2}$ enrichment on the net photosynthetic rate. Studies have indicated that the $\mathrm{CO}_{2}$ saturation point for tomato is approximately $1200-1500 \mu \mathrm{mol} \mathrm{mol}{ }^{-1}$ at the late-seedling stage (Wang et al., 2013; Ting et al., 2017). For example, Ting et al. (2017) found that the maximum photosynthetic rate of tomato seedlings is $1500 \mu \mathrm{mol} \mathrm{mol}^{-1}$ with a PPFD of $600 \mu \mathrm{mol}$ $\mathrm{m}^{-2} \mathrm{~s}^{-1}$; however, under a PPFD of $900 \mu \mathrm{mol} \mathrm{m} \mathrm{m}^{-2} \mathrm{~s}^{-1}$, a $\mathrm{CO}_{2}$ level of $1200 \mu \mathrm{mol} \mathrm{mol}^{-1}$ reached the photosynthetic rate threshold. In the present study, the net photosynthetic rate was not saturated at a PPFD of $200 \mu \mathrm{mol} \mathrm{m}^{-2} \mathrm{~s}^{-1}$ and a $\mathrm{CO}_{2}$ level of $1600 \mu \mathrm{mol} \mathrm{mol}{ }^{-1}$, which suggested that the light intensity and $\mathrm{CO}_{2}$ concentration can be further increased to increase the photosynthetic rate. However, no additional increase in the dry mass was observed in the present study when the $\mathrm{CO}_{2}$ level was enriched above $1000 \mu \mathrm{mol} \mathrm{mol}{ }^{-1}$. Since a similar leaf area was obtained with all light and $\mathrm{CO}_{2}$ treatments (same canopy light capture), an increase in the dry mass was expected with the increase in the net photosynthetic rate at a $\mathrm{CO}_{2}$ concentration of $1600 \mu \mathrm{mol} \mathrm{mol}^{-1}$. Several studies have reported a greater increase in leaf photosynthetic rate and a lower increase in plant dry mass with $\mathrm{CO}_{2}$ enrichment (Monje and Bugbee, 1998; Bunce and Sicher, 2003; Kirschbaum, 2011). A possible explanation is that the additional photoassimilates were partitioned to 


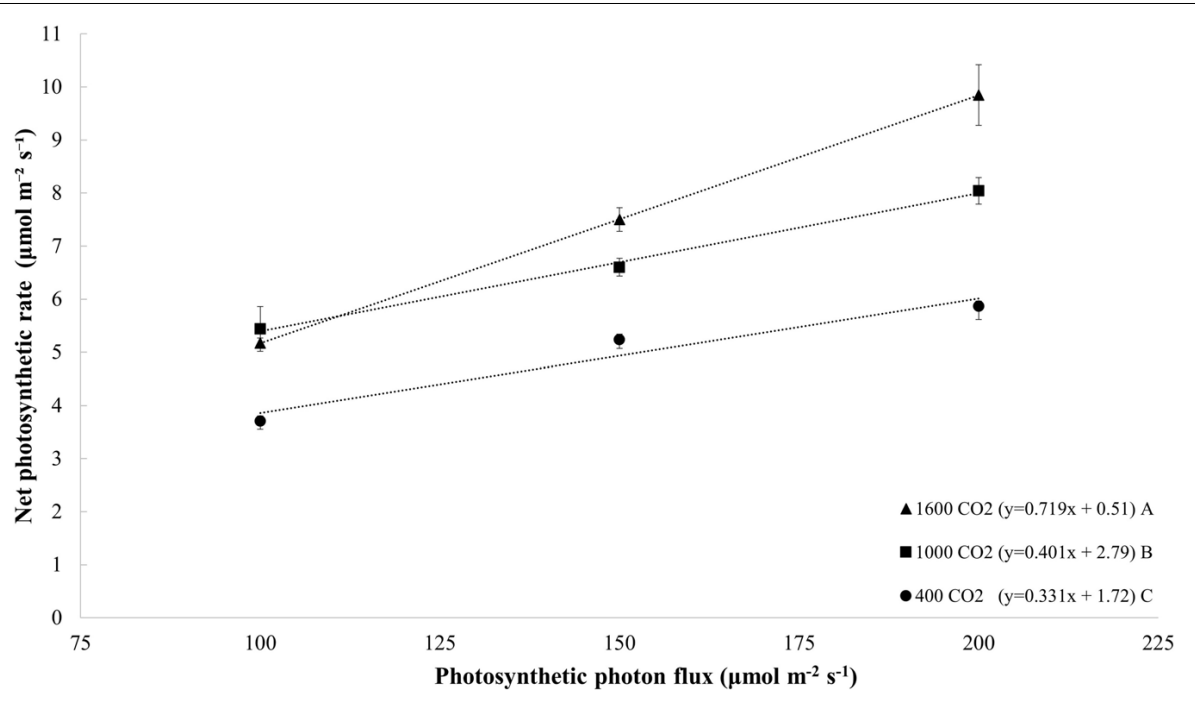

FIGURE 5 | Net photosynthetic rate ( $\mu \mathrm{mol} \mathrm{m} \mathrm{m}^{-2} \mathrm{~s}^{-1}$ ) of tomato (all cultivars) at day 20 measured at different photosynthetic photon flux densities (100, 150, and $\left.200 \mu \mathrm{mol} \mathrm{m}{ }^{-2} \mathrm{~s}^{-1}\right)$; and $\mathrm{CO}_{2}$ levels $\left(400,1000\right.$, and $\left.1600 \mu \mathrm{mol} \mathrm{mol}{ }^{-1}\right)$. The dotted lines represent significant linear fit and the equations are shown in parentheses. Different letters indicate significant differences in the slopes.

increase root growth or phytochemical biosynthesis, such as the biosynthesis of anthocyanin, and these effects were not quantified in the present study. Another possible explanation is that the increased amount of carbohydrates produced by higher photosynthetic rate could not be utilized by the plant (sink limitations) and are stored in the leaves as starch and sugars (Kirschbaum, 2011; Zheng et al., 2019).

Studies on seedlings have focused on the plant responses to either variations in the DLI or in the $\mathrm{CO}_{2}$ concentration independently, and fewer studies have investigated the responses of plants to variations in both environmental factors (Desjardins et al., 1990; Fierro et al., 1994; Pan et al., 2019). In the present study, an increase in the $\mathrm{CO}_{2}$ concentration to $1000-1600 \mu \mathrm{mol}$ $\mathrm{mol}^{-1}$ from ambient conditions increased the light use efficiency (grams of dry mass per mole of light applied) by $38-44 \%$; in addition, the comparison of the lowest light and $\mathrm{CO}_{2}$ treatment with the highest light and $\mathrm{CO}_{2}$ treatment showed an increase in the plant dry mass of $165 \%$ (Figures $2 \mathrm{~B}, 4$ ). Therefore, $\mathrm{CO}_{2}$ enrichment could be a strategy to increase the growth of young plants while reducing their energy consumption and production time (see section "Stem diameter and impact on production time"). Alternatively, $\mathrm{CO}_{2}$ enrichment to $1000-1600 \mu \mathrm{mol} \mathrm{mol}^{-1}$ and under the standard DLI $\left(13 \mathrm{~mol} \mathrm{~m}^{-2} \mathrm{~d}^{-1}\right)$ can also increase production efficiency by reducing production time and increase overall seedling growth in indoor growing systems.

The benefits of optimizing both the DLI and $\mathrm{CO}_{2}$ concentration have been shown in previous research, in which the DLIs were usually higher than $13 \mathrm{~mol} \mathrm{~m}^{-2} \mathrm{~d}^{-1}$. To our knowledge, the benefits of $\mathrm{CO}_{2}$ enrichment (greater

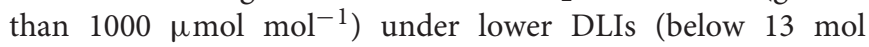
$\mathrm{m}^{-2} \mathrm{~d}^{-1}$ ) have not been previously assessed. Our study highlights the benefits of $\mathrm{CO}_{2}$ enrichment to high levels (1000$1600 \mu \mathrm{mol} \mathrm{mol}^{-1}$ ) under relatively low DLIs ranging from 6.5 to $13.0 \mathrm{~mol} \mathrm{~m}^{-2} \mathrm{~d}^{-1}$, and our findings highlight the potential of decreasing the light requirement of plants (25-50\%) through $\mathrm{CO}_{2}$ enrichment without affecting the quality of the transplants.

\section{Chlorophyll Content}

The chlorophyll content increased linearly with increases in the DLI, and this finding was obtained with all light treatments (Figure 2C). In general, the chlorophyll content per unit leaf area increased by $16 \%$ with an increase in the DLI from 6.5 to $13.0 \mathrm{~mol} \mathrm{~m} \mathrm{~m}^{-2} \mathrm{~d}^{-1}$. However, in this study, an increase in the $\mathrm{CO}_{2}$ concentration did not affect the chlorophyll content per unit leaf area (Ct/leaf area; Figure 2C).

Research with transplants have shown that an increase in the DLI increases the chlorophyll concentration per leaf area (Hernández and Kubota, 2014; Pan et al., 2019). For example, in cucumber, Hernández and Kubota (2014) found a 27\% increase in the chlorophyll concentration on a leaf area basis when the DLI was increased from 5.2 to $8.7 \mathrm{~mol} \mathrm{~m}^{-2} \mathrm{~d}^{-1}$. In addition, in tomato transplants, Pan et al. (2019) found a $41 \%$ increase in the chlorophyll content with an increase in the DLI of $2.9 \mathrm{~mol}$ $\mathrm{m}^{-2} \mathrm{~d}^{-1}$. This effect is generally attributed to an increase in the palisade rows found in thicker leaves with a lower specific leaf area as a result of a higher light intensity (Lichtenhaler et al., 1981), which allows for adaptation of the photosynthetic apparatus to capture more light when available (Boardman et al., 1975; Lichtenhaler et al., 1981).

Previous studies on $\mathrm{CO}_{2}$ enrichment have also reported a decrease in the chlorophyll content per leaf area with an increase in the $\mathrm{CO}_{2}$ concentration. For example, in tomato seedlings, $\mathrm{CO}_{2}$ enrichment to $700 \mu \mathrm{mol} \mathrm{mol}{ }^{-1}$ and $1000 \mu \mathrm{mol} \mathrm{mol}{ }^{-1}$ decreased the total chlorophyll content (Mamatha et al., 2014; Lanoue et al., 2018), whereas in rice and wheat, no increase in the chlorophyll content was observed after $\mathrm{CO}_{2}$ enrichment (Mulholland et al., 1997; Kim and You, 2010). In citrus, $\mathrm{CO}_{2}$ enrichment also reduced the chlorophyll content per unit leaf 
area by $5 \%$, but this reduction under elevated $\mathrm{CO}_{2}$ was overcome by an increase in the total leaf number (Idso et al., 1996). This decrease in the chlorophyll content as a result of $\mathrm{CO}_{2}$ enrichment is generally explained by an increase in the starch content and the presence of enlarged starch granules in leaves, which is thought to decrease chloroplast structure and function and thus decrease chlorophyll production (Cave et al., 1981; Yelle et al., 1990).

\section{Plant Morphology Hypocotyl Length, Epicotyl Length, and Seedling Total Height}

The hypocotyl, epicotyl, and total heights of the seedlings decreased linearly with increases in the DLI, and this finding was obtained with all light treatments (Figures 2D-F). In addition, the hypocotyl, epicotyl, and total heights increased linearly with increases in the $\mathrm{CO}_{2}$ level (plant height: $y=0.01 \mathrm{x}+54.2$; $R^{2}=0.31$; and $p<0.001$; data not shown). The plants grown under $\mathrm{CO}_{2}$ concentrations of $1600 \mu \mathrm{mol} \mathrm{mol}^{-1}$ exhibited higher rates of increases (slope) in the hypocotyl, epicotyl, and total heights per increase in the DLI than those grown under a $\mathrm{CO}_{2}$ concentration of $400 \mu \mathrm{mol} \mathrm{mol}^{-1}$ (Figures 2D-F). In general, under all $\mathrm{CO}_{2}$ treatments, the hypocotyl, epicotyl, and total heights increased by $25-34 \%$ when the DLI increased from 6.5 to $13.0 \mathrm{~mol} \mathrm{~m}^{-2} \mathrm{~d}^{-1}$. On average, the hypocotyl, epicotyl, and total heights increased by $24 \%$ in response to $\mathrm{CO}_{2}$ enrichment to $1600 \mu \mathrm{mol} \mathrm{mol}^{-1}$ from $400 \mu \mathrm{mol} \mathrm{mol}{ }^{-1}$.

Numerous studies have shown that increasing the DLI decreases the plant height, including the hypocotyl, epicotyl, and total heights (Fan et al., 2013; Hernández and Kubota, 2014; Gómez and Mitchell, 2015; Garcia and Lopez, 2020). For example, Garcia and Lopez (2020) found that the hypocotyl height of tomato decreased by $10 \%$ when the DLI was increased from 6.1 to $11.8 \mathrm{~mol} \mathrm{~m}^{2} \mathrm{~d}^{-1}$. Fan et al. (2013) found a $47 \%$ decrease in the total height of tomato seedlings when the DLI was increased from 2.2 to $13.0 \mathrm{~mol} \mathrm{~m}^{-2} \mathrm{~d}^{-1}$.

Previous studies have also shown that $\mathrm{CO}_{2}$ enrichment increases the overall height of transplants (Li et al., 2007b; Khan et al., 2013; Mamatha et al., 2014). For example, Li et al. (2007b) found a $22 \%$ increase in the plant height of tomato seedlings in response to $\mathrm{CO}_{2}$ enrichment to $700 \mu \mathrm{mol} \mathrm{mol}^{-1}$ from $360 \mu \mathrm{mol}$ $\mathrm{mol}^{-1} \mathrm{CO}_{2}$ in indoor systems. Similarly, a $54 \%$ increase in the total height of tomato seedlings was found after $\mathrm{CO}_{2}$ enrichment to $1000 \mu \mathrm{mol} \mathrm{mol}^{-1}$ from $400 \mu \mathrm{mol} \mathrm{mol}^{-1}$ (Lanoue et al., 2018). In greenhouse-grown tomato seedlings, Mamatha et al. (2014) found a $25 \%$ increase in the plant height after $\mathrm{CO}_{2}$ enrichment to $700 \mu \mathrm{mol} \mathrm{mol}^{-1}$ from $400 \mu \mathrm{mol} \mathrm{mol}^{-1}$. Similarly, Fan et al. (2013) found a $22 \%$ increase in the plant height in response to $\mathrm{CO}_{2}$ enrichment to $1000 \mu \mathrm{mol} \mathrm{mol}^{-1}$ from $400 \mu \mathrm{mol} \mathrm{mol}^{-1}$.

The decrease in plant height observed with increasing light intensity is an expected adaptive response of plants (Zhang et al., 2003). Low light intensities initiate shade-avoidance responses and increase stem extension to maximize light capture (Schmitt et al., 1999). Therefore, the increase in plant height triggered by increased light intensity in this study was expected. In addition, an increase in plant height with an increase in the $\mathrm{CO}_{2}$ level has been reported in the literature (Downton et al., 1990; Pushnik et al., 1995; Slafer and Rawson, 1997), and this effect is normally attributed to the increase in the growth rate leading to an overall larger plant (taller with a higher dry mass; Pritchard et al., 1999). However, in the present study, $\mathrm{CO}_{2}$ enrichment increased stem extension independently of the plant growth rate because the plant hypocotyl length and plant height were $26 \%$ higher at the same dry mass (Table 3). Therefore, the increase in the stem length obtained with $\mathrm{CO}_{2}$ enrichment can also be attributed to an increase in cell expansion due to cell wall loosening and cell water/solute uptake (Cosgrove, 1993; Ferris and Taylor, 1994; Taylor et al., 1994; Ranasinghe and Taylor, 1996; Cosgrove, 1997).

The EOD-FR light used in this study increased hypocotyl, epicotyl, and total plant heights. Therefore, the plant heights obtained with all the treatments in this study would have been reduced if the EOD-FR treatment was not included. The application of EOD-FR has been shown to increase the hypocotyl length of tomato seedlings by $12-34 \%$ (Chia and Kubota, 2010) and is a strategy used to achieve a longer hypocotyl length to compensate for the excessive compactness caused by a high blue PF in the LED spectrum. However, based on the results of this study, high $\mathrm{CO}_{2}$ levels could eliminate the need for applying EOD-FR treatment if the only goal is to manage hypocotyl extension.

\section{Leaf Area and Leaf Number}

The total leaf area per plant was not affected by increases in the DLI or $\mathrm{CO}_{2}$ level (Figure 2G), and the leaf number marginally increased with increases in the DLI $(p=0.002$; Figure $2 \mathrm{H})$ and increased linearly with increases in the $\mathrm{CO}_{2}$ level $\left(y=0.0002 \mathrm{x}+2.91 ; R^{2}=0.56\right.$; and $p<0.001$; data not shown). The plants grown under $\mathrm{CO}_{2}$ concentrations of $1600 \mu \mathrm{mol} \mathrm{mol}^{-1}$ exhibited the higher rate of increase (slope) in the leaf number with increases in the DLI, and this rate of increase was higher than that observed in the plants grown under a $\mathrm{CO}_{2}$ concentration of $1000 \mu \mathrm{mol} \mathrm{mol}^{-1}$ and $400 \mu \mathrm{mol}$ $\mathrm{mol}^{-1}$ (Figure 2H). Similarly, plants in $1000 \mu \mathrm{mol} \mathrm{mol}^{-1}$ also showed a higher rate of increase (slope) then plants in $400 \mu \mathrm{mol}$ $\mathrm{mol}^{-1}$ (Figure 2H). In general, under all $\mathrm{CO}_{2}$ treatments, the leaf number increased by $7 \%$ with an increase in the DLI from 6.5 to $13 \mathrm{~mol} \mathrm{~m}^{-2} \mathrm{~d}^{-1}$, and on average, under all DLI treatments, the leaf number increased by $8 \%$ in response to $\mathrm{CO}_{2}$ enrichment to $1600 \mu \mathrm{mol} \mathrm{mol}^{-1}$ from $400 \mu \mathrm{mol} \mathrm{mol}^{-1}$.

Although the leaf number was affected by $\mathrm{CO}_{2}$ enrichment and the DLI, the leaf area was not affected in this experiment. It was expected that plants grown under a lower DLI would increase their leaf area as a response to capture more light. Although the leaf area obtained with the different treatments was comparable, the treatments with higher $\mathrm{CO}_{2}$ and DLI resulted in a higher dry mass. Therefore, in this experiment, the increase in growth rate obtained with higher DLI and $\mathrm{CO}_{2}$ can be mainly attributed to a higher photosynthetic rate and not to an increase in the leaf area for enhanced light capture [see section "Plant growth (fresh and dry masses and net photosynthetic rate)"].

Vegetable transplant research has shown similar results where increases in the DLI had no impact on the leaf area (Currey and Lopez, 2013; Garcia and Lopez, 2020). For example, cucumber seedlings grown in a greenhouse showed no increase in leaf area 


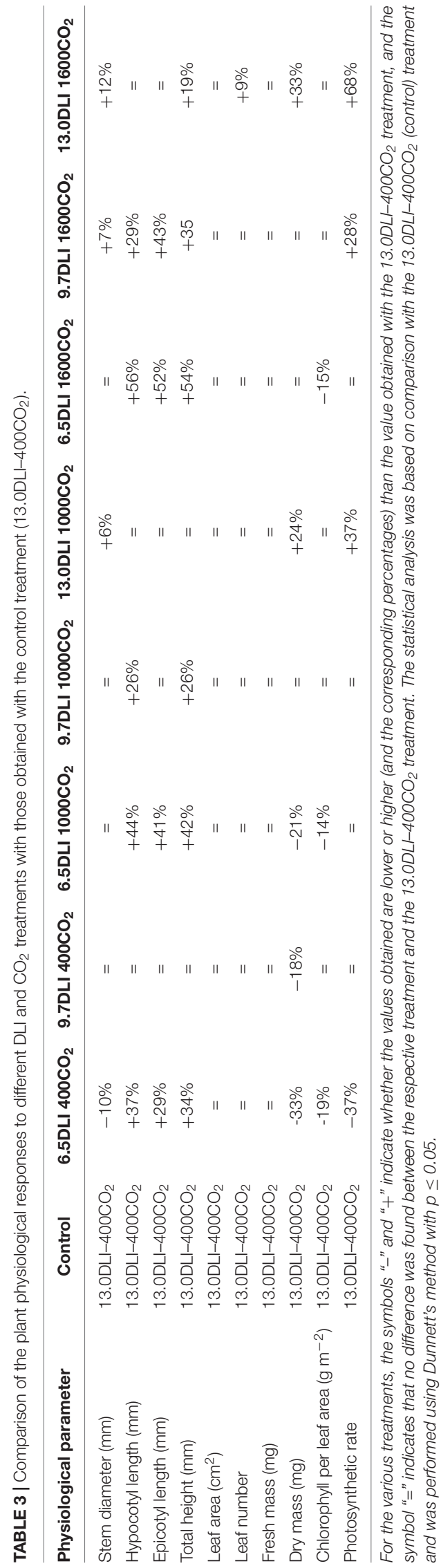

when the DLI was increased from 6.1 to $11.8 \mathrm{~mol} \mathrm{~m}^{-2} \mathrm{~d}^{-1}$ using supplemental HPS lighting (Garcia and Lopez, 2020). Similarly, ornamental plugs in a greenhouse showed no increase in leaf area when the DLI was increased from 4.5 to $9.5 \mathrm{~mol} \mathrm{~m}^{-2} \mathrm{~d}^{-1}$ using supplemental LEDs (Currey and Lopez, 2013). However, there are conflictive results when comparing the response of leaf area specifically to $\mathrm{CO}_{2}$ enrichment. For example, Pritchard et al. (1999) reviewed 63 studies and found that $57 \%$ of the studies reported an increase in the leaf area with increase in the $\mathrm{CO}_{2}$ levels, whereas $10 \%$ of the studies showed a decrease in the leaf area, and the remaining $33 \%$ observed no effect.

Another possible explanation for the lack of differences in the leaf area between the treatments could be attributed to the EOD-FR treatment used in the present study. All the plants were exposed to a EOD-FR treatment based on the reported daily dosage (intensity $\times$ duration) required to maximize (90\%) hypocotyl cell extension, which consequently will also increase leaf area (Chia and Kubota, 2010; Eguchi et al., 2016); therefore, it is plausible that leaf expansion was maximized by the EOD treatment in all $\mathrm{DLI} / \mathrm{CO}_{2}$ treatments.

Previous studies with vegetable transplants have also shown an increase in the leaf number with increases in the DLI and $\mathrm{CO}_{2}$ level (Hernández and Kubota, 2014; Mamatha et al., 2014; Pan et al., 2019; Garcia and Lopez, 2020). For example, Hernández and Kubota (2014) showed an 11\% increase in the leaf number of cucumber seedlings when the DLI was increased from 5.2$8.7 \mathrm{~mol} \mathrm{~m}^{-2} \mathrm{~d}^{-1}$. In tomato seedlings, Pan et al. (2019) found an increase of $12 \%$ in the leaf number in response to an increase in the DLI by $2.9 \mathrm{~mol} \mathrm{~m}^{-2} \mathrm{~d}^{-1}$ in a greenhouse. Similarly, Garcia and Lopez (2020) found a 16\% increase in the leaf number of tomato seedlings when the DLI was increased from 6.1 to $11.8 \mathrm{~mol} \mathrm{~m}^{-2} \mathrm{~d}^{-1}$. In response to $\mathrm{CO}_{2}$ enrichment from 380 to $700 \mu \mathrm{mol} \mathrm{mol}^{-1}$, Mamatha et al. (2014) found a $24 \%$ increase in the leaf number of tomato plants. In addition, Pan et al. (2019) found an increase in the leaf number of $18 \%$ in a greenhouse in response to $\mathrm{CO}_{2}$ enrichment $\left(800 \mu \mathrm{mol} \mathrm{mol}^{-1}\right)$, but this increase was dependent on a sufficient DLI through supplemental lighting $\left(>2.9 \mathrm{~mol} \mathrm{~m}^{-2} \mathrm{~d}^{-1}\right)$. These increases in the leaf number observed with increases in the DLI and $\mathrm{CO}_{2}$ level can be explained by the increased growth rate.

\section{Stem Diameter and Impact on Production Time}

The stem diameter of tomato seedlings increased with increases in the DLI, and this effect was observed with all light treatments ( $p<0.001$; Figure 2I). Similarly, the stem diameter increased linearly with increases in the $\mathrm{CO}_{2}$ concentration $\left(y=0.0002 \mathrm{x}+1.9 ; R^{2}=0.55\right.$; and $p<0.001$; data not shown $)$. Plants grown under a $\mathrm{CO}_{2}$ concentration of $1600 \mu \mathrm{mol} \mathrm{mol}^{-1}$ exhibited a higher rate of increase (slope) in the stem diameter per increase in the DLI than those grown under $\mathrm{CO}_{2}$ concentrations of 400 and $1000 \mu \mathrm{mol} \mathrm{mol}^{-1}$; similarly, the plants grown under a $\mathrm{CO}_{2}$ concentration of $1000 \mu \mathrm{mol} \mathrm{mol}{ }^{-1}$ exhibited higher rate of increase in the stem diameter as those grown with $400 \mu \mathrm{mol}$ $\mathrm{mol}^{-1} \mathrm{CO}_{2}$ (Figure 2I). In general, under all $\mathrm{CO}_{2}$ treatments, the stem diameter increased by $10 \%$ with an increase in the DLI from 6.5 to $13.0 \mathrm{~mol} \mathrm{~m}^{-2} \mathrm{~d}^{-1}$, and on average, under all DLI treatments, the stem diameter increased by $11 \%$ in response to 
$\mathrm{CO}_{2}$ enrichment to $1600 \mu \mathrm{mol} \mathrm{mol}{ }^{-1}$ from $400 \mu \mathrm{mol} \mathrm{mol}^{-1}$. The combination of increasing the DLI from $6.5 \mathrm{~mol} \mathrm{~m}-2 \mathrm{~d}^{-1}$ to $13.0 \mathrm{~mol} \mathrm{~m}^{-2} \mathrm{~d}^{-1}$ and the $\mathrm{CO}_{2}$ concentration from 400 to $1600 \mu \mathrm{mol} \mathrm{mol}^{-1}$ increased the stem diameter by $24 \%$.

At the seedling density used in this study (1000 plants $\mathrm{m}^{-2}$ ), the plants are grown until canopy closure and are then spaced to lower plant densities to prevent plant-to-plant competition and undesirable stretching. Several morphological factors serve as a threshold for reducing the plant density to prevent competition. For example, in tomato grafting, a stem diameter of $1.8 \mathrm{~mm}$ is often used as a threshold for both plant grafting and plant spacing. Therefore, the sooner the plant reaches this threshold, the shorter the production time. In the present study, the combination of different DLI and $\mathrm{CO}_{2}$ treatments affected the production time (time to reach $1.8 \mathrm{~mm}$ ) of tomato seedlings (Figures 6, 7). The fastest growth rate was observed under the $13 \mathrm{DLI}-1600 \mathrm{CO}_{2}$ treatment, and these plants reached the threshold in a $12 \%$ shorter time than the control plants (Figure 6). The plants subjected to the 9.7DLI-1600CO and $13 \mathrm{DLI}-1000 \mathrm{CO}_{2}$ treatments reached the threshold in a $6 \%$ shorter time than the control plants (Figure 6). Comparable growth rates to the control plants were observed under the 6.5DLI- $1600 \mathrm{CO}_{2}$ and 9.7DLI- $1000 \mathrm{CO}_{2}$ treatments, and all of these plants needed 17 days to reach the threshold (Figure 6). The plants exposed to the $6.5 \mathrm{DLI}-1000 \mathrm{CO}_{2}$ and 9.7DLI- $400 \mathrm{CO}_{2}$ treatments needed a $6 \%$ longer duration than the control plants to reach the threshold (Figure 6). These treatments with slower growth rates $\left(6.5 \mathrm{DLI}-1000 \mathrm{CO}_{2}, 9.7 \mathrm{DLI}-400 \mathrm{CO}_{2}\right.$, and $6.5 \mathrm{DLI}-$ $400 \mathrm{CO}_{2}$ ) also resulted in poor plant quality (lower shoot dry mass, smaller stem diameter, and lower chlorophyll content) and were deemed unsuitable growing conditions for transplants. The treatments that were superior or comparable to the control (13DLI-1600CO $\mathrm{CO}_{2}, 9.7 \mathrm{DLI}-1600 \mathrm{CO}_{2}, 13 \mathrm{DLI}-1000 \mathrm{CO}_{2}, 6.5 \mathrm{DLI}-$ $1600 \mathrm{CO}_{2}$, and $9.7 \mathrm{DLI}-1000 \mathrm{CO}_{2}$ ) provided suitable growing conditions for the production of high-quality tomato transplants. Based on our results, the tomato seedlings exposed to $\mathrm{CO}_{2}$ enriched concentrations of 1000 and $1600 \mu \mathrm{mol} \mathrm{mol}^{-1}$ reached the targeted stem diameter at the same time as the control plants $\left(13 \mathrm{~mol} \mathrm{~m}^{-2} \mathrm{~d}^{-1}, 400 \mu \mathrm{mol} \mathrm{mol}^{-1}\right.$ ) despite $25-50 \%$ less light (6.5 to $\left.9.7 \mathrm{~mol} \mathrm{~m}^{-2} \mathrm{~d}^{-1} \mathrm{DLI}\right)$. Furthermore, using conditions consisting of $\mathrm{CO}_{2}$ enrichment to $1000-1600 \mu \mathrm{mol}$ $\mathrm{mol}^{-1}$ and a DLI of $13 \mathrm{~mol} \mathrm{~m} \mathrm{~m}^{-1}$, tomato seedlings can be produced at $6-12 \%$ faster rate than under the control conditions (Figure 6).

Studies have shown that increasing the DLI increases the stem diameter of transplants (Fan et al., 2013; Hernández and Kubota, 2014; Pan et al., 2019; Garcia and Lopez, 2020). For example, in indoor CEs, Fan et al. (2013) found a 16\% increase in the stem diameter of tomato transplants when the DLI was increased from 2.2 to $13.0 \mathrm{~mol} \mathrm{~m}^{-2} \mathrm{~d}^{-1}$. Similarly, in cucumber transplants, Hernández and Kubota (2014) found a 20\% increase in the stem diameter when the DLI was increased from 5.2 to $8.7 \mathrm{~mol} \mathrm{~m}^{-2}$ $\mathrm{d}^{-1}$, and in pepper transplants, Garcia and Lopez (2020) found a $20 \%$ increase in the stem diameter when the DLI was increased from 6.1 to $11.8 \mathrm{~mol} \mathrm{~m}^{-2} \mathrm{~d}^{-1}$.

$\mathrm{CO}_{2}$ enrichment studies have also shown an increase in the stem diameter of transplants (Egli et al., 1997; Li et al., 2007b; Khan et al., 2013). For example, in tomato transplants, Li et al. (2007b) found a $16 \%$ increase in the stem diameter in response to $\mathrm{CO}_{2}$ enrichment from 360 to $720 \mu \mathrm{mol} \mathrm{mol}^{-1}$. Similarly, in tomato, a $24 \%$ increase in the stem diameter was found after increasing the $\mathrm{CO}_{2}$ level from 400 to $1000 \mu \mathrm{mol}$ $\mathrm{mol}^{-1}$ (Khan et al., 2013). Increases in the stem diameter have also shown benefits post-transplant. For example, an increased stem diameter of tomato transplants results in earlier yields (Liptay et al., 1981). Specifically, Liptay et al. (1981) found that transplants with stem diameters of $4.0-4.8 \mathrm{~mm}$ produced $32 \%$ more fruit at early harvest and thus exhibited a higher early yield than those with stem diameters of $3.2-4.0 \mathrm{~mm}$. The observed increase in the stem diameter is expected and is explained by an overall increase in the plant biomass obtained under higher light (Grimstad, 1987; Dorais et al., 1991; McCall, 1992) and $\mathrm{CO}_{2}$ conditions (Bencze et al., 2011; Wang et al., 2013; Ting et al., 2017).

\section{Effect of Treatment Combinations on Plant Growth, Morphology and Sustainability}

Table 3 presents the effects of the interaction of the DLI and $\mathrm{CO}_{2}$ level on plant growth and morphology. The combination treatments and their impact on plant growth and morphology were compared with standard growing conditions $\left(13 \mathrm{DLI}-400 \mathrm{CO}_{2}\right)$. Compared with the control (13DLI-400CO $\left.\mathrm{CO}_{2}\right)$ treatment, the $6.5 \mathrm{DLI}-400 \mathrm{CO}_{2}$ treatment, which involves $50 \%$ less light and the same $\mathrm{CO}_{2}$ level, produced a stretched plant (hypocotyl, epicotyl, and plant height) with a 33\% lower dry mass and reduced values for the stem diameter, chlorophyll content, and photosynthetic rate (Table 3 and Figure 7). Decreasing the DLI from 13.0 to $9.7 \mathrm{~mol} \mathrm{~m}^{-2} \mathrm{~d}^{-1}$ while maintaining the same $\mathrm{CO}_{2}$ concentration $\left(9.7 \mathrm{DLI}-400 \mathrm{CO}_{2}\right)$ produced a plant with similar morphological characteristics (stem diameter, stem extension, and chlorophyll content) to the control plants with $25 \%$ less light but with a lower dry mass (18\%), which was expected due to the reduction in the DLI (Table 3 and Figure 7).

Plants exposed to the $6.5 \mathrm{DLI}-1000 \mathrm{CO}_{2}$ treatment, which involves a 50\% lower DLI and $150 \%$ higher $\mathrm{CO}_{2}$ level than the control treatment, produced stretched plants, and the total plant height was even greater than that of the plants under the 6.5DLI-400CO $\mathrm{CO}_{2}$ treatment, which highlights the contribution of $\mathrm{CO}_{2}$ enrichment on stem extension (Table 3 and Figure 7). The plants subjected to this treatment still showed a growth rate penalty $(-21 \%)$ compared with the control plants, which was also attributed to the lower DLI.

The 9.7DLI- $1000 \mathrm{CO}_{2}$ treatment, which involves a $25 \%$ lower DLI and $150 \%$ greater $\mathrm{CO}_{2}$ level than the control treatment, produced taller plants with no penalty in the growth rate (Table 3 and Figure 7). Even though the plants subjected to this treatment exhibited a higher plant height, this effect was solely due to a longer hypocotyl, which is likely affected by the EOD-FR treatment used in the experiment. The benefit of $\mathrm{CO}_{2}$ enrichment mitigated the impact of the reduced DLI, resulting in a similar growth rate. Therefore, this DLI and $\mathrm{CO}_{2}$ combination is suitable 


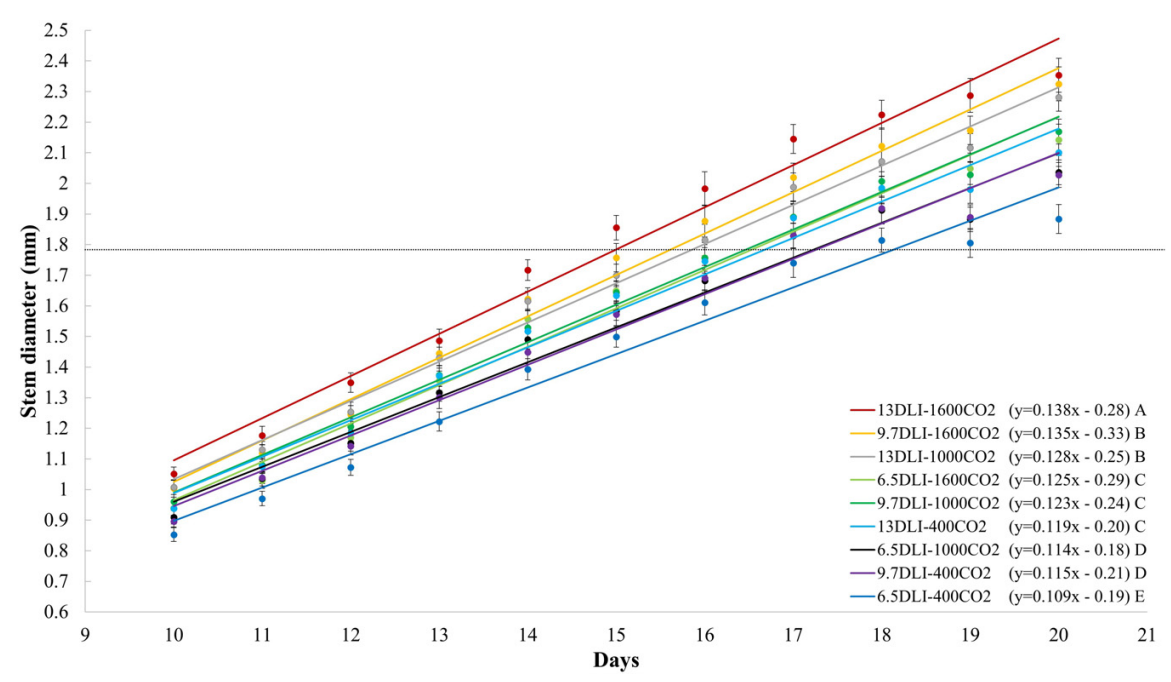

FIGURE 6 | Daily stem diameter ( $\mathrm{mm}$ ) of tomato seedlings (all cultivars) subjected to treatments with daily light integrals (DLIs: 6.5, 9.7 , and 13.0 mol $\mathrm{m}^{-2} \mathrm{~d}^{-1}$ ) and $\mathrm{CO}_{2}$ levels $\left(400,1000\right.$, and $1600 \mu \mathrm{mol} \mathrm{mol}{ }^{-1}$ ). Lines represent significant linear fit. The regression equation for each treatment is shown in parentheses. Different letters indicate significant differences in slope (rate of stem diameter increase).

for reducing light requirements while maintaining plant quality to meet commercial standards.

The $13 \mathrm{DLI}-1000 \mathrm{CO}_{2}$ treatment, which involves the same DLI and a $150 \%$ greater $\mathrm{CO}_{2}$ level compared with the control treatment, resulted in plants with similar morphological characteristics as the control plants but an increased growth rate (24\%), highlighting the benefits of $\mathrm{CO}_{2}$ enrichment on growth (Table 3 and Figure 7). Therefore, this DLI and $\mathrm{CO}_{2}$ combination is suitable for reducing the production time while maintaining plant quality to meet commercial standards.

The $6.5 \mathrm{DLI}-1600 \mathrm{CO}_{2}$ treatment, which consisted of a $50 \%$ lower DLI and a $300 \%$ greater $\mathrm{CO}_{2}$ level, produced taller plants with no penalty in the growth rate compared with the control treatment (Table 3 and Figure 7). The total plant height obtained with the $6.5 \mathrm{DLI}-1600 \mathrm{CO}_{2}$ treatment was greater than that obtained with the $6.5 \mathrm{DLI}-400 \mathrm{CO}_{2}$ and $6.5 \mathrm{DLI}-1000 \mathrm{CO}_{2}$ treatments, highlighting the contribution of $\mathrm{CO}_{2}$ enrichment to stem extension. Similar to the results obtained with the 9.7DLI- $1000 \mathrm{CO}_{2}$ treatment, the benefit of $\mathrm{CO}_{2}$ enrichment mitigated the impact of the reduced DLI in the 6.5DLI$1600 \mathrm{CO}_{2}$ treatment, which resulted in a similar growth rate with half of the light. Even though the plants subjected to this treatment exhibited a higher plant height, the increased hypocotyl length is beneficial in the production of grafted plants. Therefore, this DLI and $\mathrm{CO}_{2}$ combination is suitable for reducing light requirements and maintaining plant quality to meet commercial standards.

The 9.7DLI- $1600 \mathrm{CO}_{2}$ treatment, which involved a $25 \%$ lower DLI and a $300 \%$ greater $\mathrm{CO}_{2}$ level than the control treatment, produced taller plants with no penalty in the growth rate (Table 3 and Figure 7). The plants presented an increased plant height compared with the control plants, highlighting the contribution of $\mathrm{CO}_{2}$ enrichment to stem extension (Table 3 and Figure 7). Although the plants exposed to this treatment showed no penalty in the growth rate, an increase in the stem diameter was observed. Therefore, this DLI and $\mathrm{CO}_{2}$ combination is suitable for reducing both the light requirements and production time while maintaining plant quality to meet commercial standards. Moreover, the $13 \mathrm{DLI}-1600 \mathrm{CO}_{2}$ treatment, which consists of the same DLI and a $300 \%$ greater $\mathrm{CO}_{2}$ level than the control treatment, resulted in an increased total height with an increased growth rate (33\%), highlighting the benefits of $\mathrm{CO}_{2}$ enrichment on growth (Table 3 and Figure 7). This increase in the total height is likely due to the increased growth rate and was not specific to the hypocotyl or epicotyl. Therefore, this DLI and $\mathrm{CO}_{2}$ combination is suitable for reducing the production time and increasing plant quality above commercial standards.

The reported impacts of $\mathrm{CO}_{2}$ enrichment on plant growth and morphology in this study utilize a spectrum (1B:1R) recommended for tomato transplant production based on previous research (Liu et al., 2011; Hernández et al., 2016) which optimizes photosynthetic rate (Kim et al., 2004; Li et al., 2007b; Liu et al., 2011), fresh and dry masses (Hernández et al., 2016), and produces a compact plant. Therefore, $\mathrm{CO}_{2}$ enrichment using other light spectrums during the photoperiod would be expected to impact the results due to altered growth rates, morphology, and photosynthetic rates. Furthermore, the use of EOD-FR also impacted this response. For example, the use of EOD-FR in our study contributed to $63 \%$ longer hypocotyl length (reduced excessive compactness) and reduced intumescence (preliminary study) making them commercially acceptable. Without the use of EOD-FR; however, plants for grafting would be commercially unacceptable due to compact internodes using the current spectrum.

Though the four cultivars used in this study showed no interaction of growth or plant morphology, growth rate differences were observed for cultivar independently of those from light and $\mathrm{CO}_{2}$ as shown with tomato seedlings ( $\mathrm{Hu}$ et al., 


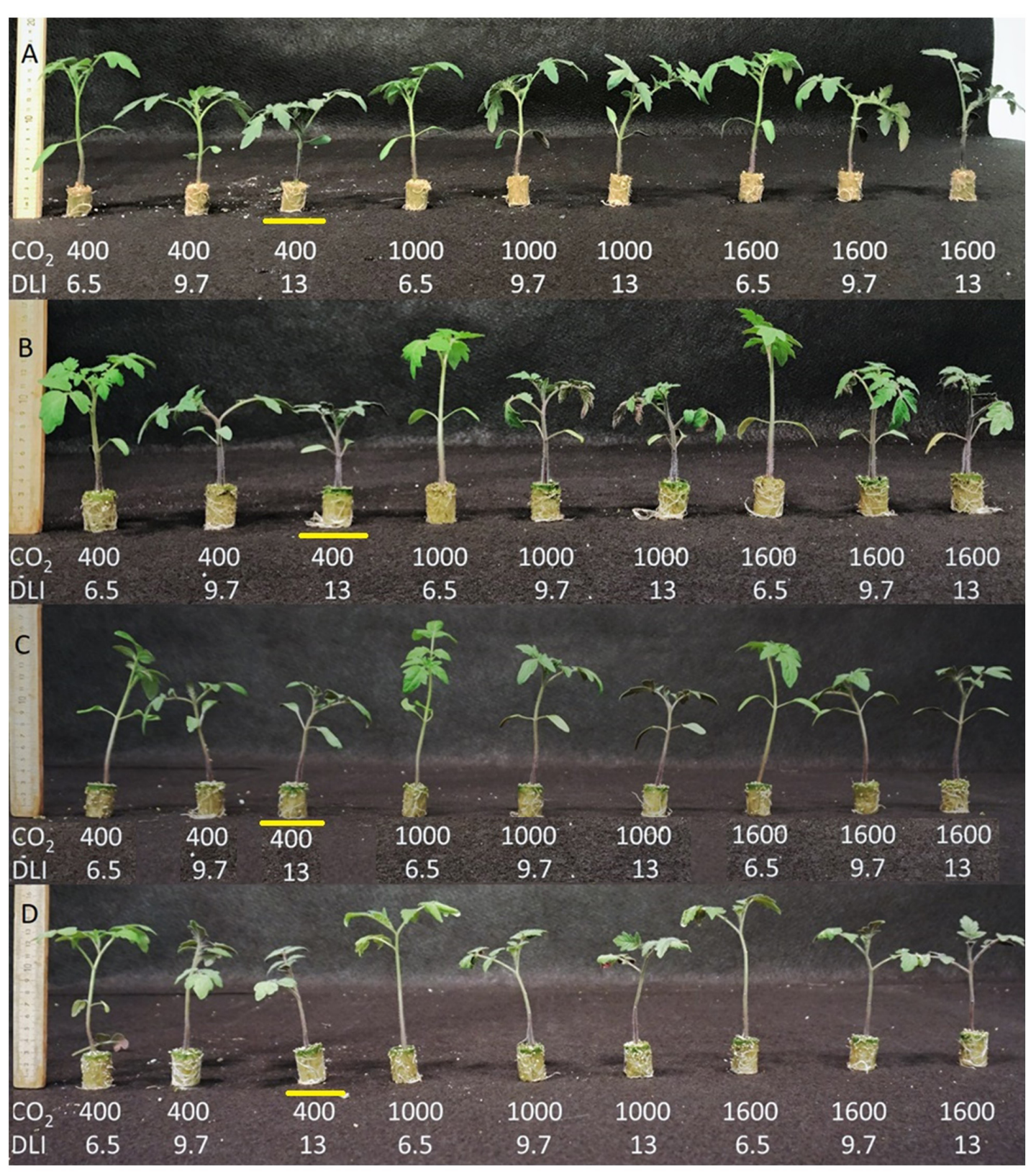

FIGURE 7 | Seedlings of the tomato cultivars Florida 47 (A), Shin Cheong Gang (B), Rebelski (C), and Maxifort (D) grown under various DLI and CO 2 conditions. All the plants were harvested when the last $\mathrm{DL} / / \mathrm{CO}_{2}$ treatment reached $1.8 \mathrm{~mm}$ (18-20 days). Commercial expected plant morphologies are shown in the control treatment $13 \mathrm{DLI} / 400 \mathrm{CO}_{2}$ which are highlighted in the image for each cultivar.

2015). For example, in our study "Shin Cheong Gang" reached a $1.8 \mathrm{~mm}$ stem diameter (grafting threshold) at day 16 , whereas "Florida-47 R" required 18 days when grown under 13DLI$400 \mathrm{CO}_{2}$. In addition, at day 18 "Shin Cheong Gang" shoot dry mass was $52 \mathrm{mg}$, whereas "Florida- $47 \mathrm{R}$ " was $77 \mathrm{mg}$ under the same environmental conditions highlighting the difference in biomass accumulation between cultivars. Therefore, growth rate and other plant morphological differences may be observed when different cultivars are used. In addition, the physiological disorder intumescence was cultivar specific in our study affecting only
"Maxifort" with 39\% symptomatic foliage, whereas "Florida-47 R," "Rebelski," and "Shin Cheong Gang" showed no symptoms. The susceptibility of interspecific tomato rootstocks such as "Maxifort" to intumescence was previously reported (Eguchi et al., 2016). Without the use of EOD-FR, intumescence severity may further impact plant growth and decrease plant quality of susceptible cultivars.

In addition to the impacts on plant growth and morphology, varying the light and $\mathrm{CO}_{2}$ levels also offers an opportunity to optimize sustainability. According to the United States 
TABLE 4 | Growing time (15-18 days), calculated energy usage of light-emitting diodes (LEDs; efficacy of LEDs used for the calculation is 3.0 $\mu$ mol $\mathrm{J}^{-1}$; kWh per growing cycle), estimated operational cost of energy required to power LEDs ( $\$ \mathrm{~m}^{-2}$ per cycle), estimated total $\mathrm{CO}_{2} \mathrm{Consumption}\left(\mathrm{kg} \mathrm{CO}_{2}\right.$ per cycle), estimated operational cost of $\mathrm{CO}_{2}$ consumption $\left(\$ \mathrm{~m}^{-2}\right.$ per cycle), and total operational cost for light and $\mathrm{CO}_{2}$ per cycle per square meter of growing area.

\begin{tabular}{|c|c|c|c|c|c|c|}
\hline Treatment & Days to $1.8 \mathrm{~mm}$ & Total energy for lighting $\mathbf{k W h}$ & Lighting cost $\$ \mathrm{~m}^{-2}$ & Total $\mathrm{CO}_{2} \mathrm{~kg} \mathrm{CO}$ & $\mathrm{CO}_{2}$ cost $\$ \mathrm{~m}^{-2}$ & Total cost $\$ \mathrm{~m}^{-2}$ \\
\hline $6.5 \mathrm{DLI}-400 \mathrm{CO}_{2}$ & 18 & 13.33 & $\$ 1.20$ & 0.36 & $\$ 0.21$ & $\$ 1.41$ \\
\hline 9.7DLI-400CO 2 & 17 & 18.89 & $\$ 1.70$ & 0.48 & $\$ 0.28$ & $\$ 1.98$ \\
\hline 13.0DLI-400CO 2 & 17 & 25.19 & $\$ 2.26$ & 0.54 & $\$ 0.31$ & $\$ 2.57$ \\
\hline $6.5 \mathrm{DLI}-1000 \mathrm{CO}_{2}$ & 17 & 12.59 & $\$ 1.13$ & 0.53 & $\$ 0.31$ & $\$ 1.44$ \\
\hline 9.7DLI-1000CO 2 & 17 & 18.89 & $\$ 1.70$ & 0.64 & $\$ 0.37$ & $\$ 2.07$ \\
\hline 13.0DLI-1000CO 2 & 16 & 23.70 & $\$ 2.13$ & 0.73 & $\$ 0.42$ & $\$ 2.55$ \\
\hline $6.5 \mathrm{DLI}-1600 \mathrm{CO}_{2}$ & 17 & 12.59 & $\$ 1.13$ & 0.54 & $\$ 0.32$ & $\$ 1.45$ \\
\hline $9.7 \mathrm{DLI}-1600 \mathrm{CO}_{2}$ & 16 & 17.78 & $\$ 1.60$ & 0.71 & $\$ 0.41$ & $\$ 2.01$ \\
\hline 13.0DLI-1600CO 2 & 15 & 22.22 & $\$ 2.00$ & 0.86 & $\$ 0.50$ & $\$ 2.50$ \\
\hline
\end{tabular}

Department of Agriculture, sustainability involves five different components: (1) efficient use of nonrenewable resources, (2) enhanced environmental quality, (3) sustained economic viability, (4) satisfactory human food and fiber needs, and (5) enhanced quality of life of producers. A comprehensive evaluation of the components was not performed in this study, but the results regarding the usage of energy and $\mathrm{CO}_{2}$ (sustainability components 1 and 2) and the overall cost of light and $\mathrm{CO}_{2}$ (sustainability component 3 ) are presented in Table 4 . The calculation of $\mathrm{CO}_{2}$ usage utilized a room air exchange rate of $0.1 \mathrm{~h}^{-1}$, which is still a very low ventilation rate. Therefore, most of the $\mathrm{CO}_{2}$ provided is used for plant growth and is not released outside the growing environment.

The total energy and the total $\mathrm{CO}_{2}$ consumed to meet the different DLI and $\mathrm{CO}_{2}$ conditions are provided per square meter and growing cycle for every treatment combination (Table 4). When considering energy usage, production cost, and plant quality (growth and morphology) combined, the 9.7DLI-1000CO $2,13 \mathrm{DLI}-1000 \mathrm{CO}_{2}, 6.5 \mathrm{DLI}-1600 \mathrm{CO}_{2}, 9.7 \mathrm{DLI}-$ $1600 \mathrm{CO}_{2}$, and $13 \mathrm{DLI}-1600 \mathrm{CO}_{2}$ treatment combinations are suitable for improving the sustainability of the current production practices $\left(13 \mathrm{DLI}-400 \mathrm{CO}_{2}\right)$. For example, the 9.7DLI-1000CO $\mathrm{CO}_{2}$, 6.5DLI-1600CO $\mathrm{CO}_{2}$, and $9.7 \mathrm{DLI}-1600 \mathrm{CO}_{2}$ treatments resulted in reductions in the energy usage of 19 , 44 , and $22 \%$, respectively, which led to reductions in the production cost of 19,44 , and $22 \%$, respectively, compared with the control treatment. The treatments with the same DLI as the control but a higher level of $\mathrm{CO}_{2}$ (13DLI$1000 \mathrm{CO}_{2}$ and $13 \mathrm{DLI}-1600 \mathrm{CO}_{2}$ ) also resulted in a small reduction in the production cost (1-3\%) while reducing production time (6-12\%) and increasing plant growth (24$33 \%$ ). The cost of $\mathrm{CO}_{2}$ enrichment to $1600 \mu \mathrm{mol} \mathrm{mol}^{-1}$ is minimal in contained systems $\left(0.1 \mathrm{~h}^{-1}\right)$. Although the most economical treatment per cycle might be desirable, growers may benefit in producing more cycles per year based on the $13 \mathrm{DLI}-1600 \mathrm{CO}_{2}$ treatment.

\section{CONCLUSION}

Despite the use of DLIs below the commercial standards $\left(13.0 \mathrm{~mol} \mathrm{~m}^{-2} \mathrm{~d}^{-1}\right), \mathrm{CO}_{2}$ enrichment showed benefits on the growth and morphology of tomato transplants and maintained plant quality. Due to $\mathrm{CO}_{2}$ enrichment, the DLI requirements for producing tomato transplants can be reduced by $25-50 \%$ without affecting plant quality, which would reduce the production costs by up to $44 \%$. Although hypocotyl elongation was observed with the treatments consisted of a lower DLI, this morphological characteristic can be controlled by the light spectrum. Alternatively, if a bigger plant with lower production time is desired, then maintaining a DLI of $13.0 \mathrm{~mol} \mathrm{~m}^{-2} \mathrm{~d}^{-1}$, $\mathrm{CO}_{2}$ enrichment at $1600 \mu \mathrm{mol} \mathrm{mol}^{-1}$ can reduce the production time by $12 \%$ and produce plants with a similar morphology and reduce costs by $3 \%$.

With the increase in the light efficacy of LED lights, it is now possible to increase the production efficacy and sustainability of indoor systems by environmental optimization. The present study details the responses of tomato plants to two environmental components (light and $\mathrm{CO}_{2}$ ) and highlights an opportunity to optimize production based on selected goals. For example, largescale tomato production can be optimized based on one or several of the following priorities: increase plant growth, reduce the production time, obtain a desired plant architecture, reduce energy usage, and/or increase affordability.

Future studies should investigate the post-transplant acclimation of these plants to field conditions and should focus on optimizing other environmental conditions to further optimize controlled environment systems.

\section{DATA AVAILABILITY STATEMENT}

The raw data supporting the conclusions of this article will be made available by the authors, without undue reservation.

\section{AUTHOR CONTRIBUTIONS}

BH: study conception and design, acquisition of data, analysis and interpretation of data, and drafting of manuscript. FL: analysis and interpretation of data, drafting of manuscript, critical revision, and funding acquisition. RH: study conception and design, analysis and interpretation of data, drafting of 
manuscript, critical revision, and funding acquisition. All authors contributed to the article and approved the submitted version.

\section{FUNDING}

Funding for this research was provided by a USDA-NIFA specialty crop research initiative, growing new roots: Grafting

\section{REFERENCES}

Aldrich, R. A., and Bartock, J. W. (1994). Greenhouse Engineering; NRAES-Natural Resources, Agriculture, and Engineering Service, Vol. 33. Ithaca, NY: Northeast Regional Agricultural Engineering Service.

Bauerle, W. L. (1984). Bag culture production of greenhouse tomatoes. Ohio State Univ. Spec. Circ. 108:7.

Behboudian, M. H., and Lai, R. (1994). Carbon dioxide enrichment in 'Virosa' tomato plant: responses to enrichment duration and to temperature. HortScience 29, 1456-1459. doi: 10.21273/hortsci.29.12.1456

Bencze, S., Keresztenyi, I., Varga, B., Koszegi, B., Balla, K., Gemesne-Juhasz, A., et al. (2011). Effect of $\mathrm{CO}_{2}$ enrichment on canopy photosynthesis, water use efficiency and early development of tomato and pepper hybrids. Acta Agronom. Hungar. 59, 275-284. doi: 10.1556/aagr.59.2011.3.12

Bjorkman, O. (1981). "Responses to different quantum flux densities," in Physiological Plant Ecology 1. Responses to the Physical Environment, eds O. L. Lange, P. S. Nobel, C. B. Osmond, and H. Ziegler (Berlin: Springer-Verlag), 57-107. doi: 10.1007/978-3-642-68090-8_4

Boardman, N. K., Björkman, O., Anderson, J. M., Goodchild, D. J., and Thorne, S. W. (1975). Photosynthetic adaptation of higher plants to light intensity: relationship between chloroplast structure, composition of the photosystems and photosynthetic rates. Photosynth. Res. 3, 1809-1827.

Both, A. J., Frantz, J. M., and Bugbee, B. (2017). "Carbon dioxide enrichment in controlled environments," in Light Management in Controlled Environments, eds R. Lopez and E. Runkle (Willoughby, OH: Meister Media), 82-90.

Bunce, J. A., and Sicher, R. C. (2003). Daily irradiance and feedback inhibition of photosynthesis at elevated carbon dioxide concentration in brassica oleracea. Photosynthetica 41, 481-488. doi: 10.1023/b:phot.0000027511. 44995.66

Calvert, A., and Slack, G. (1975). Effects of carbon dioxide enrichment on growth, development and yield of glasshouse tomatoes. I. Responses to controlled concentrations. HortScience 50, 61-71. doi: 10.1080/00221589.1975.11514604

Cave, G., Tolley, L. C., and Strain, B. R. (1981). Effect of carbon dioxide enrichment on chlorophyll content, starch content and starch grain structure in Trifolium subterraneum leaves. Physiol. Plant. 51, 171-174. doi: 10.1111/j.1399-3054. 1981.tb02694.x

Chia, P. L., and Kubota, C. (2010). End-of-day far-red light quality and dose requirements for tomato rootstock hypocotyl elongation. HortScience 45, 15011506. doi: 10.21273/hortsci.45.10.1501

Cosgrove, D. J. (1993). Wall extensibility: its nature, measurement, and relationship to plant cell growth. New Phytol. 124, 1-23. doi: 10.1111/j.1469-8137.1993. tb03795.x

Cosgrove, D. J. (1997). Relaxation in a high-stress environment: the molecular bases of extensible cell walls and cell enlargement. Plant Cell 9, 1031-1041. doi: 10.1105/tpc.9.7.1031

Craver, J. K. (2014). The Effects of UVB Radiation on Intumescence Development and the Characterization of Lesions from Physiological Disorders on Ornamental Sweet Potato (Ipomoea batatas) Tomato (Solanum lycopersicum) and Interspecific Geranium (Pelargonium spp.). MS thesis, Kansas State University, Manhattan, KS.

Currey, C. J., and Lopez, R. (2013). Cuttings of impatiens, pelargonium, and petunia propagated under light-emitting diodes and high-pressure sodium lamps have comparable growth, morphology, gas exchange, and posttransplant performance. HortScience 48, 428-434. doi: 10.21273/HORTSCI.48. 4.428 to enhance resiliency in U.S. vegetable industries under award number 2016-51181-25404.

\section{ACKNOWLEDGMENTS}

The authors would like to express gratitude to Cristian Collado, Hans Spalholz, Xiangnan Xu, and the NCSU Phytotron staff for their assistance with this research.

Desjardins, Y., Gosselin, A., and Lamarre, M. (1990). Growth of transplants and in vitro-cultured clones of asparagus in response to $\mathrm{CO}_{2}$ enrichment and supplemental lighting. HortScience 115, 364-368. doi: 10.21273/jashs.115.3.364

Dorais, M. (2003). "The use of supplemental lighting for vegetable crop production: light intensity, crop response, nutrition, crop management, cultural practices," in Proceedingsof the Canadian Greenhouse Conference Toronto, Ontario. 23 May 2013. Available online at: http://www.agrireseau.qc.ca/legumesdeserre/ Documents/CGC-Dorais2003fin2.PDF (accessed October 9, 2003).

Dorais, M., Gosselin, A., and Trudel, M. J. (1991). Annual greenhouse tomato production under a sequential intercropping system using supplemental light. Sci. Horticult.45, 225-234. doi: 10.1016/0304-4238(91)90067-9

Downton, W. J. S., Grant, W. J. R., and Chako, E. K. (1990). Effect of elevated carbon dioxide on the photosynthesis and early growth of mangosteen (Garcinia mangostana L.). Sci. Horticult. 44, 215-225. doi: 10.1016/03044238(90)90121-T

Egli, P., Maurer, S., Gunthardt-Goerg, M. S., and Korner, C. (1997). Effects of elevated $\mathrm{CO}_{2}$ and soil quality on leaf gas exhange and above-ground growth in beech-spruce model ecosystems. New Phytol. 140, 185-196. doi: 10.1046/j. 1469-8137.1998.00276.x

Eguchi, T., Hernández, R., and Kubota, C. (2016). Far-red and blue light synergistically mitigate intumescence injury of tomato plants grown under ultraviolet-deficit light environment. HortScience 51, 712-719. doi: 10.21273/ hortsci.51.6.712

Eichhorn-Bilodeau, B. S., Wu, B. S., Rufyikiri, A. S., MacPherson, S., and Lefsrud, M. (2019). An update on plant photobiology and implications for cannabis production. Front. Plant Sci. 10:296. doi: 10.3389/fpls.2019.00296

Enoch, H. Z., Rylski, I., and Spigelman, M. (1976). $\mathrm{CO}_{2}$ enrichment of strawberry and cucumber plants growing in unheated greenhouses in Israel. Sci. Horticult. 5, 33-41. doi: 10.1016/0304-4238(76)90020-0

Fan, X., Xu, Z., Liu, X., Tang, C., Wang, L., and Han, X. (2013). Effects of light intensity on the growth and leaf development of young tomato plants grown under a combination of red and blue light. Sci. Horticult. 153, 50-55. doi: 10.1016/j.scienta.2013.01.017

Ferris, R., and Taylor, G. (1994). Elevated $\mathrm{CO}_{2}$, water relations and biophysics of leaf extension in four chalk grassland herbs. New Phytol. 127, 297-307. doi: 10.1111/j.1469-8137.1994.tb04280.x

Fierro, A., Gosselin, A., and Tremblay, N. (1994). Supplemental carbon dioxide and light improved tomato and pepper seedling growth and yield. HortScience 29, 152-154. doi: 10.21273/HORTSCI.29.3.152

Garcia, C., and Lopez, R. G. (2020). Supplemental radiation quality influences cucumber, tomato, and pepper transplant growth and development. HortScience 55, 804-811. doi: 10.21273/hortsci14820-20

Geider, R. J., and McIntyre, H. L. (2002). "Physiology and biochemistry of photosynthesis and algal carbon acquisition," in Phytoplankton Productivity: Carbon, Assimilation in Marine and Freshwater Ecosystems, eds P. J. Williams, D. N. Thomas, and C. S. Reynolds (Oxford: Blackwell), 44-77. doi: 10.1063/1. 39754

Gómez, C., and Mitchell, C. A. (2015). Growth responses of tomato seedlings to different spectra of supplemental lighting. HortScience 50, 112-118. doi: 10.21273/hortsci.50.1.112

Grimstad, S. O. (1987). Supplementary lighting of early tomatoes after planting out in glass and acrylic greenhouses. Sci. Horticult.33, 189-196. doi: 10.1016/03044238(87)90066-5

Hao, X. Y., Li, P., Li, H. Y., Zong, Y. Z., Zhang, B., Zhao, J. Z., et al. (2017). Elevated $\mathrm{CO}_{2}$ increased photosynthesis and yield without decreasing stomatal 
conductance in broomcorn millet. Photosynthetica 55, 176-183. doi: 10.1007/ s11099-016-0226-6

Hernández, R., Eguchi, T., Deveci, M., and Kubota, C. (2016). Tomato seedling physiological responses under different percentages of blue and red photon flux ratios using LEDs and cool white fluorescent lamps. Sci. Horticult. 213, 270-280. doi: 10.1016/j.scienta.2016.11.005

Hernández, R., and Kubota, C. (2014). Growth and morphological response of cucumber seedlings to supplemental red and blue photon flux ratios under varied solar daily light integrals. Sci. Horticult. 173, 92-99. doi: 10.1016/j. scienta.2014.04.035

Hernández, R., and Kubota, C. (2015). Physiological responses of cucumber seedlings under different blue and red photon flux ratios using LEDs. Environ. Exp. Bot. 121, 66-74. doi: 10.1016/j.envexpbot.2015.04.001

Hu, B., Bennett, M. A., and Kleinhenz, M. D. (2016). A new method to estimate vegetable seedling vigor, piloted with tomato, for use in grafting and other contexts. Hort Technology 26, 767-775. doi: 10.21273/horttech03485-16

Hu, B., Moyseenko, J., Short, S., Walker, S., and Kleinhenz, M. D. (2015). Eighteen Rootstock and Five Scion Tomato Varieties: Seedling Growth Rates Before Grafting and Success in Grafting the Ninety Variety Combinations. Purdue Fruit and Vegetable Research Reports. Paper 95. Available online at: https://docs.lib. purdue.edu/fvtrials/95 (accessed September 12, 2020).

Idso, S. B., Kimball, B. A., and Hendrix, D. L. (1996). Effects of atmospheric $\mathrm{CO}_{2}$ enrichment on chlorophyll and nitrogen concentrations of sour orange tree leaves. Environ. Exp. Bot. 36, 323-331. doi: 10.1016/0098-8472(96)01018-0

Jensen, M. H., and Malter, A. J. (1995). Protected Agriculture: A Global Review. Washington, DC: World Bank Technical Paper No. 253. 157.

Kaskavalci, G., Tuzel, Y., Dura, O., and Oztekin, G. B. (2009). Effects of alternative control methods against Meloidogyne incognita in organic tomato production. Ekoloji 18, 23-31. doi: 10.5053/ekoloji.2009.724

Khah, E. M., Kakava, E., Mavromatis, A., Chachalis, D., and Goulas, G. (2006). Effect of grafting on growth and yield of tomato (Lycopersicon esculentum Mill.) in greenhouse and open field. J. Appl. Horticult. 8, 3-7. doi: 10.37855/jah.2006. v08i01.01

Khan, I., Azam, A., and Mahmood, A. (2013). The impact of enhanced atmospheric carbon dioxide on yield, proximate composition, elemental concentration, fatty acid and vitamin C contents of tomato (Lycopersicon esculentum). Environ. Monitor. Asses. 185, 205-214. doi: 10.1007/s10661-012-2544-x

Kim, H. R., and You, Y. H. (2010). The effects of the elevated $\mathrm{CO}_{2}$ concentration and increased temperature on growth, yield, and physiological responses of Rice (Oryza sativa L. cv. Junam). Adv. Biores. 1, 46-50.

Kim, S. J., Hahn, E. J., Heo, J. W., and Paek, K. Y. (2004). Effects of LEDs on net photosynthetic rate, growth, and leaf stomata of chrysanthemum plantlets in vitro. Sci. Horticult. 101, 143-151. doi: 10.1016/j.scienta.2003.10.003

Kirschbaum, M. U. F. (2011). Does enhanced photosynthesis enhance growth? Lessons learned from $\mathrm{CO}_{2}$ enrichment studies. Plant Physiol. 155, 117-124. doi: $10.1104 /$ pp.110.166819

Kozai, T. (2005). "Closed systems for high quality transplants using minimum resources," in Plant Culture Engineering, eds S. D. Gupta and Y. Ibaraki (Berlin: Springer), 275-312. doi: 10.1007/1-4020-3694-9_15

Kozai, T. (2007). Propagation, grafting, and transplant production in closed systems with artificial lighting for commercialization in Japan. J. Ornam. Plants 7, 145-149.

Kozai, T. (2013). Resource use efficiency of closed plant production system with artificial light: concept, estimation and application to plant factory. Proc. Jpn. Acad. Ser. B 89, 447-461. doi: 10.2183/pjab.89.447

Kozai, T. (2018). Smart Plant Factory: Next-Generation Indoor Vertical Farms. Singapore: Springer. doi: 10.1007/978-981-13-1065-2

Kubota, C., McClure, M. A., Kokalis-Burelle, N., Bausher, M. G., and Rosskopf, E. N. (2008). Vegetable grafting: history, use, and current technology status in North America. HortScience 43, 1664-1669. doi: 10.21273/hortsci.43.6.1664

Labeke, M. C. V., and Dambre, P. (1998). Effect of supplementary lighting and $\mathrm{CO}_{2}$ enrichment on yield and flower stem quality of Alstroemeria cultivars. Sci. Horticult. 74, 269-278. doi: 10.1016/s0304-4238(98)00091-0

Lang, S. P., and Tibbitts, T. W. (1983). Factors controlling intumescence development on tomato plants. HortScience 108, 93-98.

Lanoue, J., Leonardos, E. D., Khosia, S., Hao, X., and Grodzinski, B. (2018). Effect of elevated $\mathrm{CO}_{2}$ and spectral quality on whole plant gas exchange patterns in tomatoes. PLoS One 13:e0205861. doi: 10.1371/journal.pone.0205861
Lewis, J. D., Wang, X. Z., Griffin, K. L., and Tissue, D. T. (2002). Effects of age and ontogeny on photosynthetic responses of a determinate annual plant to elevated $\mathrm{CO}_{2}$ concentrations. Plant Cell Environ. 25, 359-368. doi: 10.1046/j.0016-8025. 2001.00815.x

Lewis, M., Kubota, C., Tronstad, R., and Son, Y. (2014). Scenario-based cost analysis for vegetable grafting nurseries of diffeernt technologies and sizes. HortScience 49, 917-930. doi: 10.21273/HORTSCI.49.7.917

Li, J., Zhou, J., Duan, Z. Q., Du, C. W., and Wang, H. Y. (2007a). Effect of $\mathrm{CO}_{2}$ enrichment on the growth and nutrient uptake of tomato seedlings. Pedosphere 17, 343-351. doi: 10.1016/S1002-0160(07)60041-1

Li, J., Zhou, J. M., and Duan, Z. Q. (2007b). Effects of elevated $\mathrm{CO}_{2}$ concentration on growth and water usage of tomato seedlings under different ammonium/nitrate ratios. J. Environ. Sci. 19, 1100-1107. doi: 10.1016/S10010742(07)60179-X

Lichtenhaler, H. K., Buschmann, C., Doll, M., Fietz, H. J., Bach, T., Kozel, U., et al. (1981). Photosynthetic activity, chloroplast ultrastructure, and leaf charateristics of high-light and low-light plants and of sun and shade leaves. Photosynth. Res. 2, 115-141. doi: 10.1007/bf00028752

Liptay, A., Jaworski, C. A., and Phatak, S. C. (1981). Effect of tomato transplant stem diameter and ethephon treatment on tomato yield, fruit size and number. Canad. J. Plant Sci. 61, 413-415. doi: 10.4141/cjps81-056

Liu, X. Y., Chang, T. T., Guo, S. R., Xu, Z. G., and Li, J. (2011). Effect of different light quality of LED on growth and photosynthetic character in cherry tomato seedling. Acta Hort 907, 325-330. doi: 10.17660/actahortic.2011.907.53

Lopez, R., and Runkle, E. S. (2017). Light Management in Controlled Environments. Willoughby, OH: Meister Media Worldwide.

Louws, F. J., Rivard, C. L., and Kubota, C. (2010). Grafting fruiting vegetables to manage soilborne pathogens, foliar pathogens arthropods and weeds. Sci. Horticult. 127, 127-146. doi: 10.1016/j.scienta.2010.09.023

Mamatha, H., Rao, N. K. S., Laxman, R. H., Shivashankara, K. S., Bhatt, R. M., and Pavithra, K. C. (2014). Impact of elevated $\mathrm{CO}_{2}$ on growth, physiology, yield, and quality of tomato (Lycopersicon esculentum Mill) cv. Arka Ashish. Photosynthetica 52, 519-528. doi: 10.1007/s11099-014-0059-0

McAvoy, T., Freeman, J. H., Rideout, S. L., Olson, S. M., and Paret, M. L. (2012). Evaluation of grafting using hybrid rootstocks for management of bacterial wilt in field tomato production. HortScience 47, 621-625. doi: 10.21273/hortsci.47. 5.621

McCall, D. (1992). Effect of supplementary light on the tomato transplant growth, and the after-effects on yield. Sci. Horticult. 51, 65-70. doi: 10.1016/03044238(92)90104-k

Monje, O., and Bugbee, B. (1998). Adaptation to high $\mathrm{CO}_{2}$ concentration in an optimal environment: radiation capture, canopy quantum yield and carbon use efficiency. Plant Cell Environ. 21, 315-324. doi: 10.1046/j.1365-3040.1998. 00284.x

Moran, R., and Porath, D. (1980). Chlorophyll determination in intact tissues using N, N-dimethylformamide. Plant Physiol. 65, 478-479. doi: 10.1104/pp.65.3.478

Mortensen, L., and Moe, R. (1983). Growth responses of some greenhouse plants to environment. V. Effect of $\mathrm{CO}_{2}, \mathrm{O} 2$ and light on net photosynthetic rate in Chrysanthemum morifolium Ramat. Sci. Horticult. 19, 133-140. doi: 10.1016/ 0304-4238(83)90053-5

Mulholland, B. J., Craigon, J., Black, C. R., Colls, J. J., Atherton, J., and Landon, G. (1997). Impact of elevated atmospheric $\mathrm{CO}_{2}$ and $\mathrm{O}_{3}$ on gas exchange and chlorophyll content in spring wheat (Triticum aestivum L.). J. Exp. Bot. 48, 1853-1863. doi: 10.1093/jexbot/48.315.1853

Naing, A. H., Jeon, S. M., Park, J. S., and Kim, C. K. (2016). Combined effects of supplementary light and $\mathrm{CO}_{2}$ on rose growth and the production of good quality cut flowers. Canad. J. Plant Sci. 96, 503-510. doi: 10.1139/cjps-20150304

Nanfelt, M. (2016). Hydroponic Crop Farming, IBISWorld Industry Report OD4012. Washington, DC: World Bank Group.

Nilsen, E. T., Sharifi, M. R., Rundel, P. W., Jarrell, W. M., and Virginia, R. (1983). Diurnal and seasonal water relations of the desert phreatophyte Prosopis glandulosa (honey mesquite) in the Sonoran Desert of California. Ecology 64, 1381-1393. doi: 10.2307/1937492

O'Carrigan, A., Hinde, E., Lu, N., Xu, X. Q., Duan, H. L., Huang, G. M., et al. (2014). Effects of light irradiance on stomatal regulation and growth of tomato. Environ. Exp. Bot. 98, 65-73. doi: 10.1016/j.envexpbot.2013. 10.007 
Oda, M. (1999). Grafting of vegetables to improve greenhouse production. Food Fertil. Technol. Center Exten. Bul. 480, 1-11.

Ohyama, K., and Kozai, T. (1998). Estimating electric energy consumption and its cost in a transplant production factory with artificial lighting: a case study. Shokubutsu Kojo Gakkaishi 10, 96-107. doi: 10.2525/jshita.10.96

Ohyama, K., Kozai, T., and Chun, C. (2003). Development and application of closed transplant production system (in Japanese). J Shita 15, 1-10.

Ohyama, K., Kozai, T., and Yoshinaga, K. (2000). "Electric energy, water and carbon dioxide utilization efficiencies of closed-type transplant production system," in Transplant production in the 21st Century, eds C. Kubota and C. Chun (Dordrecht: Kluwer Academic), 28-32.

Orellana, M. V., and Perry, M. J. (1992). An immunoprobe to measure Rubisco concentrations and maximal photosynthesis rates of individual phytoplankton cells. Limnol. Oceanogr. 37, 978-990. doi: 10.4319/lo.1992.37.3.0478

Pan, T. H., Ding, J. J., Qin, G. G., Wang, Y. L., Xi, L. J., Yang, J. W., et al. (2019). Interaction of supplementary light and $\mathrm{CO}_{2}$ enrichment improves growth, photosynthesis, yield, and quality of tomato in autumn through spring greenhouse production. Hortscience 54, 246-252. doi: 10.21273/ HORTSCI13709-18

Pramuk, L. A., and Runkle, E. S. (2005). Photosynthetic daily light integral during the seedling stage influences subsequent growth and flowering of celosia, impatiens, salvia, tagetes, and viola. HortScience 40, 1099C-1099C. doi: 10. 21273/hortsci.40.4.1099c

Pritchard, S. G., Rogers, H. H., Prior, S. A., and Peterson, C. M. (1999). Elevated $\mathrm{CO}_{2}$ and plant structure: a review. Glob. Change Biol. 5, 807-837. doi: 10.1046/ j.1365-2486.1999.00268.x

Pushnik, J., Demaree, R., Houpis, J., Flory, W., Bauer, S., and Anderson, P. (1995). The effect of elevated carbon dioxide on a Sierra-Nevadan dominant species: Pinus ponderosa. J. Biogeogr. 22, 249-254. doi: 10.2307/2845918

Ranasinghe, S., and Taylor, G. (1996). Mechanism for increased leaf growth in elevated $\mathrm{CO}_{2}$. J. Exp. Bot. 47, 349-358. doi: 10.1093/jxb/47.3.349

Reinert, R. A., Eason, G., and Barton, J. (1997). Growth and fruiting of tomato as influenced by elevated carbon dioxide and ozone. New Phytol. 137, 411-420. doi: 10.1046/j.1469-8137.1997.00846.x

Rivard, C. L., O'Connell, S., Peet, M., and Louws, F. J. (2010). Grafting tomato with interspecific rootstock to manage diseases caused by Sclerotium rolfsii and southern root-knot nematode. Plant Dis. 94, 1015-1021. doi: 10.1094/PDIS-948- 1015

Rivkin, R. B. (1990). Photoadaptation in marine phytoplakton: variations in ribulose 1,5-bisphosphate activity. Mar. Ecol. Progr. Ser. 62, 61-72. doi: 10.3354/ meps062061

Schmitt, J., Dudley, S. A., and Pigliucci, M. (1999). Manipulative approaches to testing adaptive plasticity: phytochrome-mediated shade-avoidance responses in plants. Am. Natural. 154, S43-S54. doi: 10.1086/303282

Shi, J., and Le Maguer, M. (2000). Lycopene in tomatoes: chemical and physical properties affected by food processing. Crit. Rev. Biotechnol. 20, 293-334. doi: $10.1080 / 07388550091144212$

Singh, H., Kumar, P., Chaudhari, S., and Edelstein, M. (2017). Tomato grafting: a global perspective. HortScience 52, 1328-1336. doi: 10.21273/HORTSCI1199617

Slafer, G. A., and Rawson, H. M. (1997). $\mathrm{CO}_{2}$ effects on phasic development, leaf number and rate of leaf appearance in wheat. Ann. Bot. 79, 75-81. doi: 10.1006/anbo.1996.0305

Sukenik, A., Bennett, J., and Falkowski, P. (1987). Light-saturated photosynthesisLimitation by electron transport or carbon fixation? Biochim. Biophys. Acta Bioenerg. 891, 205-215.
Taylor, G., Ranasinghe, S., Bosac, C., Gardner, S. D. L., and Ferris, R. (1994). Elevated $\mathrm{CO}_{2}$ and plant growth: cellular mechanisms and responses of whole plants. J. Exp. Bot. 45, 1761-1774. doi: 10.1093/jxb/45.special_issue.1761

Ting, L., Yuhan, K., Man, Z., Sha, S., and Minzan, L. (2017). Universality of an improved photosynthesis prediction model based on PSO-SVM at all growth stages of tomato. Int. J. Agricult. Biol. 10, 63-73.

Torres, A., and Lopez, R. (2011). Commercial Greenhouse Production. Measuring Daily Light Integral in a Greenhouse. West Lafayette, IN: Purdue Extension.

U.S. Department of Agriculture (2016). Vegetables 2015 Summary. Available online at: https://www.nass.usda.gov/Publications/Todays_Reports/reports/vegean17. pdf (accessed December 19, 2016).

Uzun, S. (2006). The quantitative effects of temperature and light on the number of leaves preceding the first fruiting inflorescence on the stem of tomato (Lycopersicon esculentum, Mill.) and aubergine (Solanum leongena L.). Sci. Horticult. 109, 142-146. doi: 10.1016/j.scienta.2006.04.006

Wang, H., Gu, M., Cui, J., Shi, K., Zhou, Y., and Yu, J. (2009). Effects of light quality on $\mathrm{CO}_{2}$ assimilation, chlorophyll-fluorescence quenching, expression of calvin cycle genes and carbohydrate accumulation in Cucumis sativus. J. Photochem. Photobiol. 96, 30-37. doi: 10.1016/j.jphotobiol.2009.03.010

Wang, W. Z., Zhang, M., Liu, C. H., Li, M. Z., and Liu, G. (2013). Real-time monitoring of environmental information and modeling of the photosynthetic rate of tomato plants under greenhouse conditions. Appl. Eng. Agric. 29, 783-792. doi: $10.13031 /$ aea.29.9743

Xu, X., and Hernández, R. (2020). The effect of light intensity on vegetative propagation efficacy, growth, and morphology of "Albion" strawberry plants in a precision indoor propagation system. Appl. Sci. 10:1044. doi: 10.3390/ app 10031044

Yarsi, G. (2011). Effects of grafted seedling use on yield, growth and quality parameters of tomato growing in greenhouse. Acta Hort 923, 311-314. doi: 10.17660/ActaHortic.2011.923.46

Yelle, S., Beeson, R. C. Jr., Trudel, M. J., and Gosselin, A. (1990). Duration of $\mathrm{CO}_{2}$ enrichment influences growth, yield, and gas exchange of two tomato species. HortScience 115, 52-57. doi: 10.21273/jashs.115.1.52

Zhang, S., Ma, K., and Chen, L. (2003). Response of photosynthetic plasticity of Paeonia suffruticosa to changed light environments. Environ. Exp. Bot. 49, 121-133. doi: 10.1016/s0098-8472(02)00063-1

Zheng, Y., Li, F., Hao, L., Yu, J., Guo, L., Zhou, H., et al. (2019). Elevated $\mathrm{CO}_{2}$ concentration induces photosynthetic down-regulation with changes in leaf structure, non-structural carbohydrates and nitrogen content of soybean. $B M C$ Plant Biol. 19:255. doi: 10.1186/s12870-019-1788-9

Ziska, L. H., Sicher, R. C., and Kremer, D. F. (1995). Reversibility of photosynthetic acclimation of swiss chard and sugarbeet grown at elevated concentrations of $\mathrm{CO}_{2}$. Physiol. Plant. 95, 355-364. doi: 10.1034/j.1399-3054.1995.950 304.x

Conflict of Interest: The authors declare that the research was conducted in the absence of any commercial or financial relationships that could be construed as a potential conflict of interest.

Copyright () 2021 Huber, Louws and Hernández. This is an open-access article distributed under the terms of the Creative Commons Attribution License (CC BY). The use, distribution or reproduction in other forums is permitted, provided the original author(s) and the copyright owner(s) are credited and that the original publication in this journal is cited, in accordance with accepted academic practice. No use, distribution or reproduction is permitted which does not comply with these terms. 